\title{
Neogene evolution of the Carpatho-Pannonian region: an interplay of subduction and back-arc diapiric uprise in the mantle
}

\author{
V. Konečný ${ }^{1}$, M. Kováč ${ }^{2}$, J. Lexa ${ }^{1}$, and J. Šefara ${ }^{3}$ \\ ${ }^{1}$ Geological Survey of Slovak Republic, Mlynská dolina 1, 81704 Bratislava, Slovakia \\ ${ }^{2}$ Comenius University, Fac. of Sci., Department of geology and paleontology, Mlynská dolina, 84215 Bratislava, Slovakia \\ ${ }^{3}$ Comenius University, Fac. of Sci., Department of applied geophysics, Mlynská dolina, 84215 Bratislava, Slovakia
}

Received: 19 December 2000 - Revised: 24 October 2001 - Accepted: 30 October 2001

\begin{abstract}
Geodynamic evolution of the Carpathian arc and Pannonian basin during the Neogene times is presented as a set of palinspastic reconstructions. The structural evolution is modeled in terms of a coupled system of: (1) Alpine (Atype) subduction and compressive orogene belt development owing to compression by the Adriatic microplate, (2) lateral extrusion of Alcapa lithosphere from the Alpine collision assisted by transform faults, (3) Carpathian gravity driven (Btype) subduction of oceanic or suboceanic lithosphere underlying former flysch basins and (4) back arc extension associated with the diapiric uprise of asthenospheric mantle.

The variable timing of accretionary prism and back arc basin evolution in the Western Carpathians, the NW part of the Eastern Carpathians, and the SE part of the Eastern Carpathians confirms that the final Tertiary evolution of the Carpathian arc and Pannonian basin was not a uniform process. Rather, it took place successively in three segments, reflecting gravity driven subductions compensated by return asthenospheric flows (involving the back-arc diapiric uprise of asthenospheric mantle). The observed low subduction rate implies obstacles to the compensating asthenosphere flow, perhaps represented by confining thick lithosphere at the NW and SE sides of the arc. This segmentation may arise from a gravity driven process allowing asthenospheric side flow to take place speeding up the gravity driven overturn (subduction). Structural evolution as well as the timing and spatial distribution of the arc-type (subduction-related) andesite volcanics suggests that subduction halted because the subducting plate became nearly vertical, followed closely by the detachment of the sinking lithosphere slab from the continental margin. Late stage alkali basalt volcanic rocks imply that during the final stage of back arc basin evolution the related diapiric uprise of asthenospheric mantle incorporated unmetasomatized mantle material, brought possibly into the area of the diapiric uprise by compensating athenosheric mantle counterflows.
\end{abstract}

Correspondence to: J. Lexa (lexa@gssr.sk)
Key words. Neogene; Carpathian arc; Pannonian basin; subduction; asthenospheric diapir; volcanism; structural development; palinspastic reconstruction

\section{Introduction}

Geologists have repeatedly attempted to explain the Neogene evolution of the Carpatho-Pannonian region, in terms of an extensive Pannonian basin system bounded by a young Carpathian orogenic arc. Naturally, successive models reflect advances in geotectonic thinking. While older models were based on geological data alone, newer ones included an interpretation of geophysical data. The presence of rocks of accretionary prisms and andesite volcanic units, combined with evidence of thinned crust and lithosphere and the high heat flow in the Pannonian basin region, led during the seventies and early eighties to the first applications of plate tectonic principles (Bleahu et al., 1973; Boccaletti et al., 1973; Radeluscu and Sandulescu, 1973; Stegena et al., 1975; Lexa and Konečný, 1974, 1979; Balla, 1980, 1981; Horváth and Royden, 1981). Subduction models were introduced to explain the Tertiary evolution of the Carpathian orogenic arc and models of diapiric uprise of asthenospheric mantle were intorduced to explain Neogene Pannonian back arc basin development.

Subsequent recognition of major fault zones with an extensive lateral displacement gave geotectonic modelling a new impetus reflected in the concept of microplates (e.g. Royden et al., 1982; Balla, 1984) and finally led to the model of lateral extrusion of the Alcapa microplate from the Alpine collision zone (Ratchbacher et al., 1991a, b) and to an integrated model of Carpatho-Pannonian region evolution applying principles of subduction rollback, back-arc diapiric uprise of asthenospheric mantle, and lateral extrusion of lithosphere assisted by transform faults (Royden, 1988, 1993b; Csontos et al., 1991, 1992; Horváth, 1993; Csontos, 1995; 
Kováč et al., 1994, 1998; Huismans et al., 1997; Linzer et al., 1998). This comprehensive model was strongly supported by results of paleomagnetic measurements indicating large scale rotations of microplates (Balla, 1987; Márton et al., 1995; Márton and Márton, 1996; Panaiotu, 1998) and by the extent of shortening in the Carpathian flysch basins during their transformation into an accretionary prism (e.g. Oszczypko and Slaczka, 1986; Oszczypko, 1997; Kováč et al., 1989, 1998; Roure et al., 1993; Morley, 1996; Nemčok et al., 1998).

An interpretation of the Vranca deep seismic zone in conection with detached sinking lithosphere slab (Constantinescu and Enescu, 1984) and the recognition of subducted lithosphere remnants underneath the Pannonian basin and internal Carpathian units (Spakman, 1990) resulted in the concept of final verticalization of the subduction zone, slab detachment, related deep subsurface load, and platform margin bending (Vortel and Spakman, 1992; Meulenkamp et al., 1996; Krzywiec and Jochym, 1997; Nemčok et al., 1998; Zoetemeijer et al., 1999). These gravity driven processes were not contemporaneous along the arc - rather they show a progression from west to east during the Early Miocene to Quaternary time (Vortel and Spakman, 1992; Nemčok et al., 1998; Lexa and Konečný, 1998, Kováč, 2000).

The aim of this review paper is not to present new data, but to demonstrate that the final Neogene evolution of the Carpathian arc and Pannonian basin was not a uniform process. The set of palinspastic reconstructions (models) presented here documents geodynamic evolution of three segments (parts) of the whole system, indicating gravity driven subduction compensated by return asthenospheric flows, including back-arc diapiric uprise of asthenospheric mantle in time and space.

\section{Geophysical evidence}

The crustal thickness of the Pannonian basin realm varies in the range $22-35 \mathrm{~km}$ (e.g. Horváth, 1993). Areas of thin crust along with corresponding extension basins mark zones of the most intense lithosphere stretching, evidenced by high heatflow (Royden and Dövényi 1998). Hence, areas of relatively thicker crust represent crustal blocks unaffected by stretching (back arc extension).

Figure 1 summarizes essential data concerning lithosphere and asthenosphere. The lithospheric thickness in part " $a$ " is based on seismological and magnetotelluric sounding data (modified after Lenkey, 1999; Horváth, 1993; Spakman et al., 1993; Bielik et al., 2000). A rather thin lithosphere of the Pannonian basin is surrounded by a thick, continental type lithosphere. The apparently thick lithosphere in the Vranca region, accompanied by deep seismicity, is interpreted in terms of ongoing subduction. The thick lithosphere west of the Pannonian basin corresponds to the collision orogene of the Eastern Alps with considerable shortenning (Lillie et al., 1994). Absence of thicker lithosphere underneath the Carpathian arc rules out a collision as the principal tectonic mechanism. Rather, we envision gentle docking of the arc to the continental margin (Lillie et al., 1994), accompanied by microplate rotations (e.g. Kováč and Márton, 1998; Panaiotu, 1998). The shallow position of the lithosphere/asthenosphere boundary underneath the Pannonian basin indicates asthenosphere upwelling (diapiric uprise) during the Tertiary period of active stretching.

Detached lithospheric slabs in the asthenosphere underneath the Carpathian arc and Pannonian basin have been identified by seismic tomography and thermal modelling. Figure $1 \mathrm{~b}$ shows variability of the seismic wave velocities in the section from the Pannonian basin to the Bohemian massif, according to Spakman et al. (1993). The high-velocity zone at depths of $300-400 \mathrm{~km}$ is interpreted as a detached and sunken lithospheric slab. Rejuvenated lower boundaries of the crust and lithosphere (Horváth, 1993) are also indicated. Figure 1c shows a thermal model along a section from the Pannonian basin to the East European platform (Gordijenko in Buryanov et al., 1987). The relatively cool zone at a depth $250-350 \mathrm{~km}$ underneath the Pannonian basin is also interpreted as a detached and sunken lithospheric slab.

The continental margin hidden underneath the accretionary prism of the Carpathian arc was interpreted using results of reflection seismics and gravity modelling (Tomek et al., 1989; Tomek and Hall, 1993; Bielik et al., 2000). It runs close to the Pieniny Klippen belt in the West; while to the east it follows the Krosno-Moldavian flysch zone. The present position of the continental margin probably corresponds to the final position of the youngest subduction zone of the Carpathian orogene.

\section{Evidence provided by Tertiary volcanic rocks}

On the basis of spatial distribution, relation to tectonics, compositional features, and assumed petrological models, Lexa et al. (1993) distinguished in the Carpatho-Pannonian region four groups of the Neogene to Quaternary volcanic rocks: areal type (extension-related) silicic volcanics, areal type (extension-related) andesite volcanics, arc type (subductionrelated) basaltic andesite to andesite volcanics, and alkali basalt volcanics. Pécskay et al. (1995) recorded also a sporadic occurrence of shoshonitic and ultrapotassic rocks. Their distribution in space and time is shown in Figs. 2-6. Geotectonic implications follow from the relevant petrological models. Here we shall use the ones worked out by Lexa and Konečný (1998).

The areal type (extension-related) silicic volcanics are represented by dacites to silica-rich rhyolites form extensive sheets of tuffs and ignimbrites, with dome/flow complexes in source areas. They are generally peraluminous, corresponding in composition to S-type granite magmas. The fact that voluminous areal type silicic volcanics mostly do not associate with intermediate or mafic rocks indicates that silicic rocks of this type are most probably of crustal origin. Isotopic data indicate a dominant crustal component (Salters et al., 1988). However, initiation of magma generation by par- 
a) $\quad \begin{array}{lllll}0 & 100 & 200 & 300 & 400 \mathrm{~km}\end{array}$
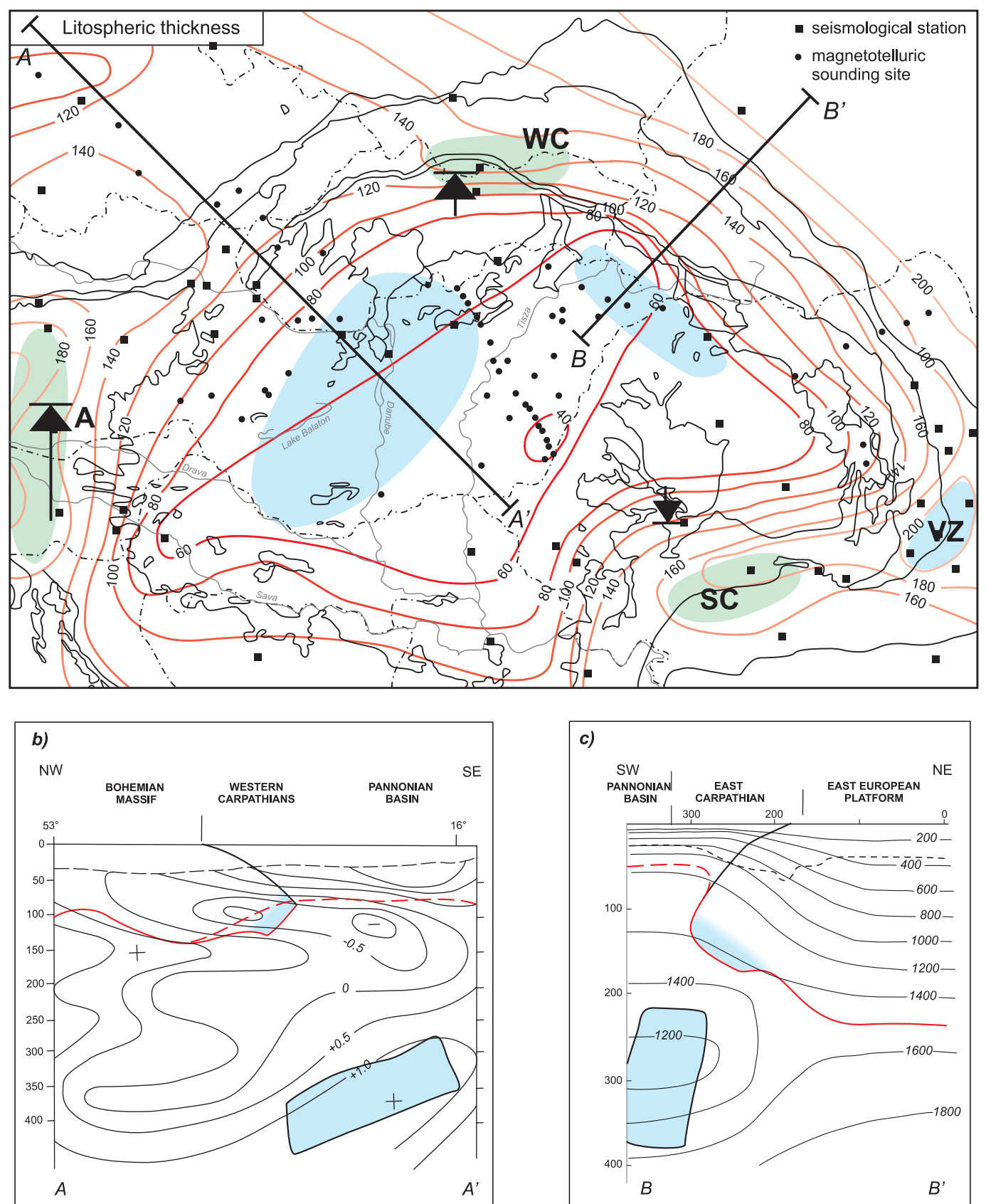

c)
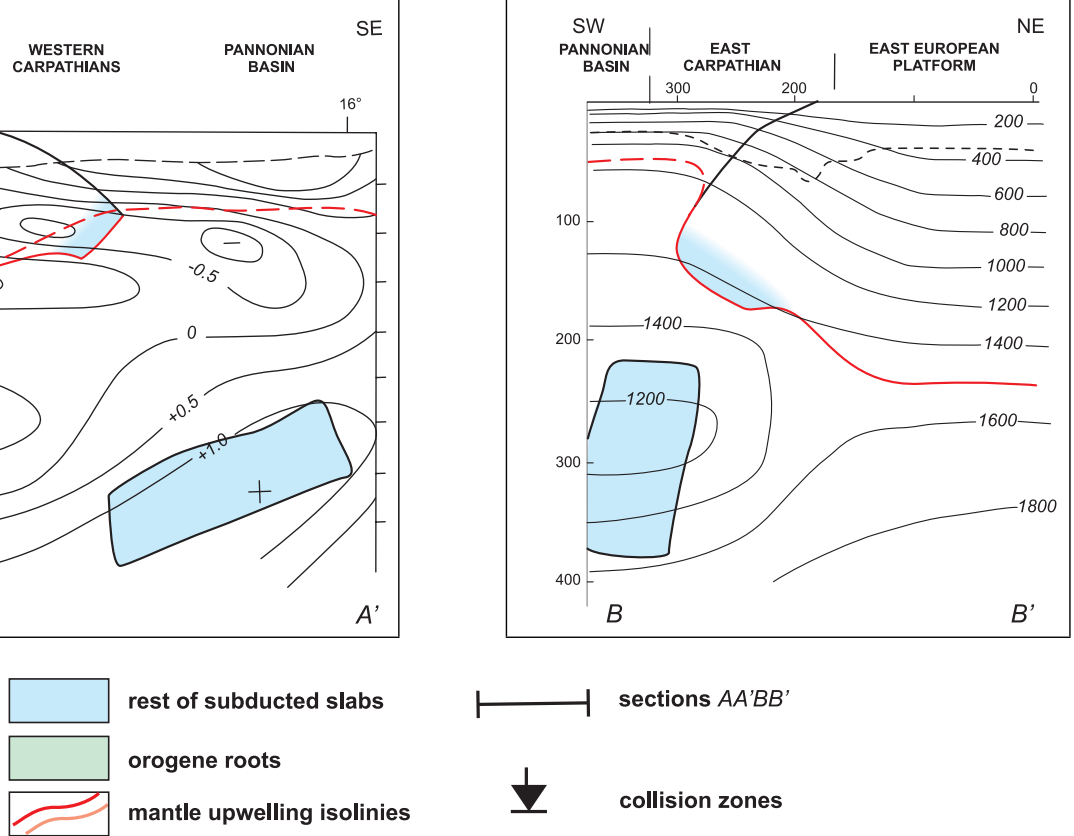

$\longmapsto$ sections $A A^{\prime} B B^{\prime}$

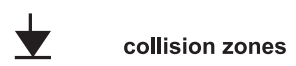

Fig. 1. Asthenosphere upwelling and relics of subducted lithosphere slabs below the Carpatho-Pannonian region - geophysical evidence. For commentary see text.

tial melting in the mantle is indicated by isotopic evidence suggesting a "mantle component" in silicic magmas and by a rare occurrence of andesites of the same age (Pécskay et al., 1995). It follows that required crustal anatexis was most probably caused by heating induced by extension-related di- apiric uprise of the asthenospheric mantle associated with emplacement of mantle-derived hydrous basaltic magmas at the base of a relatively thick continental crust (Póka, 1988; Lexa and Konečný, 1998). Downes (1996) has proposed an alternative model of lithospheric delamination, bringing hot 
asthenospheric material into direct contact with crustal material to explain anatectic melting of the crust. So, in either case, presence of these magmas implies initial stages of the back arc transtension and extension affecting relatively thick continental crust and related back arc diapiric uprise of asthenospheric mantle (e.g. Lexa and Konečný, 1998).

The areal type (extension-related) andesite volcanics are represented dominantly by intermediate to basic andesites in the form of stratovolcanoes with a substantial presence of subvolcanic intrusive rocks and differentiated rocks as dome/flow complexes and or pyroclastic horizons (Gyarmati, 1977; Konečný et al., 1995a; Roşu et al., 1998; Korpás et al., 1998). Subordinate late stage rhyolite volcanics are present in some regions. In the northeastern part of the Pannonian basin areal type andesite volcanics alternate with abundant products of the areal type silicic volcanics (Gyarmati, 1977; Pécskay et al., 1995). The areal type andesite volcanics are mostly of the high-K type, showing compositional features comparable with andesites of continental margins (Lexa and Konečný, 1998). Rare shoshonitic andesites (Styrian basin) and adakites (Apuseni Mts.) have been reported recently (Pécskay et al., 1995; Roşu et al., 2001). An interpretation of trace element contents and $\mathrm{Sr}, \mathrm{Nd}, \mathrm{Pb}$ and $\mathrm{O}$ isotopic compositions (Salters et al., 1988; Downes et al., 1995a) indicates a source of primary basaltic magmas in enriched asthenosphere (lithosphere?), with subsequent contamination by crustal materials. Further evolution of magmas involved both high- and low-pressure fractionation, assimilation, anatexis of crustal material, and mixing (Lexa et al., 1998). Lack of a space and time relationship to active subduction, and a close relationship in space and time to basin and range type extension tectonics in the back-arc setting (Kaličiak et al., 1989; Nemčok and Lexa, 1990), support a petrological model in which magma generation is initiated by decompression partial melting of the enriched athenosphere and/or lithosphere owing to athenosphere upwelling and related lithosphere delamination (Lexa and Konečný, 1998; Roşu et al., 2001). Presence of extension-related areal type andesite volcanics (including shoshonites and adakites) indicates (1) a preceding stage of subduction responsible for mantle enrichment especially in volatile components, (2) advanced stages of the back arc extension affecting progressively thinning crust, and (3) related advanced diapiric uprise of asthenospheric mantle.

Arc type (subduction-related) basaltic andesite to andesite volcanics are represented mainly by andesite stratovolcanoes with subordinate differentiated rocks and/or subvolcanic intrusive rocks (Kaličiak and Žec, 1995; Szakács and Szegedi, 1995). Extrusive domes and/or shallow intrusions are present only at the westernmost and Tibles-Toroiaga segments of the volcanic arc. Alignment of volcanoes (extrusive domes, intrusions) parallel to the Carpathian arc is the most prominent structural feature. A large proportion of basaltic andesites and generally lower content of potassium and incompatible elements in comparison with the areal type andesite volcanics are characteristic from the compositional point of view. These basaltic andesites and andesites are mostly of the medium-K type, showing a great deal of similarity with andesites of evolved island arcs and continental arcs. In the case of Tibles-Toroiaga intrusions, Calimani volcanoes, and Hargita volcanoes there is even a correspondence with high$\mathrm{K}$ andesites of continental margins (Kaličiak and Žec, 1995; Lyashkevich, 1995; Seghedi et al., 1995). Some of the internally situated andesite occurrences show to various degrees relative potassium and incompatible element enrichment (a transition to the shoshonitic trend). The strongest shoshonitic compositional features have been observed at the western end of the andesite arc in small intrusions near Uherské Hradište (Pøichystal et al., 1988) and at the eastern end of the arc in lava flows near Bixad and Malnas, Southern Hargita, Romania (Seghedi et al., 1995). Geochemical characteristics as well as the space-time distribution of these volcanics were controlled directly by ongoing subduction processes in the same way as it is known from active island arcs in the Pacific and Mediterranean. In the case of the Calimani - Ghurghiu Hargita volcanoes in the Eastern Carpathians various aspects of the petrologic model were discussed in detail by Mason et al. (1995, 1996) and Seghedi et al. (1995). Nemčok et al. (1998) argued that volcanics of this type might also be generated owing to detachment of the subducting lithosphere slab. Using the analogy of active volcanic arcs, the presence of the arc type basaltic andesite to andesite volcanics indicates: (1) a real and deep reaching subduction, (2) the extent and geometry of the subduction zone, (3) the time at which subducting lithosphere reached the magma generation depth and/or the time of the lithosphere slab detachment, (4) duration of the subduction process.

Alkali basalt volcanics are represented by alkali olivine basalts, nepheline basanites and rare trachybasalts, hawaiites, trachytes and potassic alkali rocks (Mihaliková and Šímová, 1989; Harangi et al., 1995; Dobosi et al., 1995; Pécskay et al., 1995). They make up dispersed groups of maars, tuff cones, cinder cones, lava flows, diatremes, necks and dykes. Petrologic aspects of alkali basalt volcanics were recently evaluated by Embey-Isztin et al. (1993), Dobosi et al. (1995), Downes et al. (1995b) and Harangi et al. (1995). Alkali basalts and nepheline basanites are products of decompression partial melting in depleted asthenospheric mantle with a variable relict (especially isotopic) subduction signature. Composition of magmas was controlled mostly by degree of partial melting, less important were processes of fractionation leading to trachytic and potassic compositions. Recent processes of diapiric uprise in the mantle related to generation of alkali basalts in southern Slovakia are indicated by PT conditions of equilibration of mantle xenoliths, which fall on the adiabatic trend in the depth interval 50-90 km (Huraiová and Konečný, 1993; P. Konečný et al., 1995). So, the presence of alkali basalt volcanics indicates: (1) arrival and involvement of asthenosphere not affected by subduction processes, (2) a local diapiric uprise in the asthenosphere with a large enough vertical displacement to generate alkali basalt magmas, (3) an end of the convergence and subduction processes in the closely situated segments of the arc, (4) an extension environment owing to continuing subduction in the 


\section{EGGENBURGIAN - OTTNANGIAN}

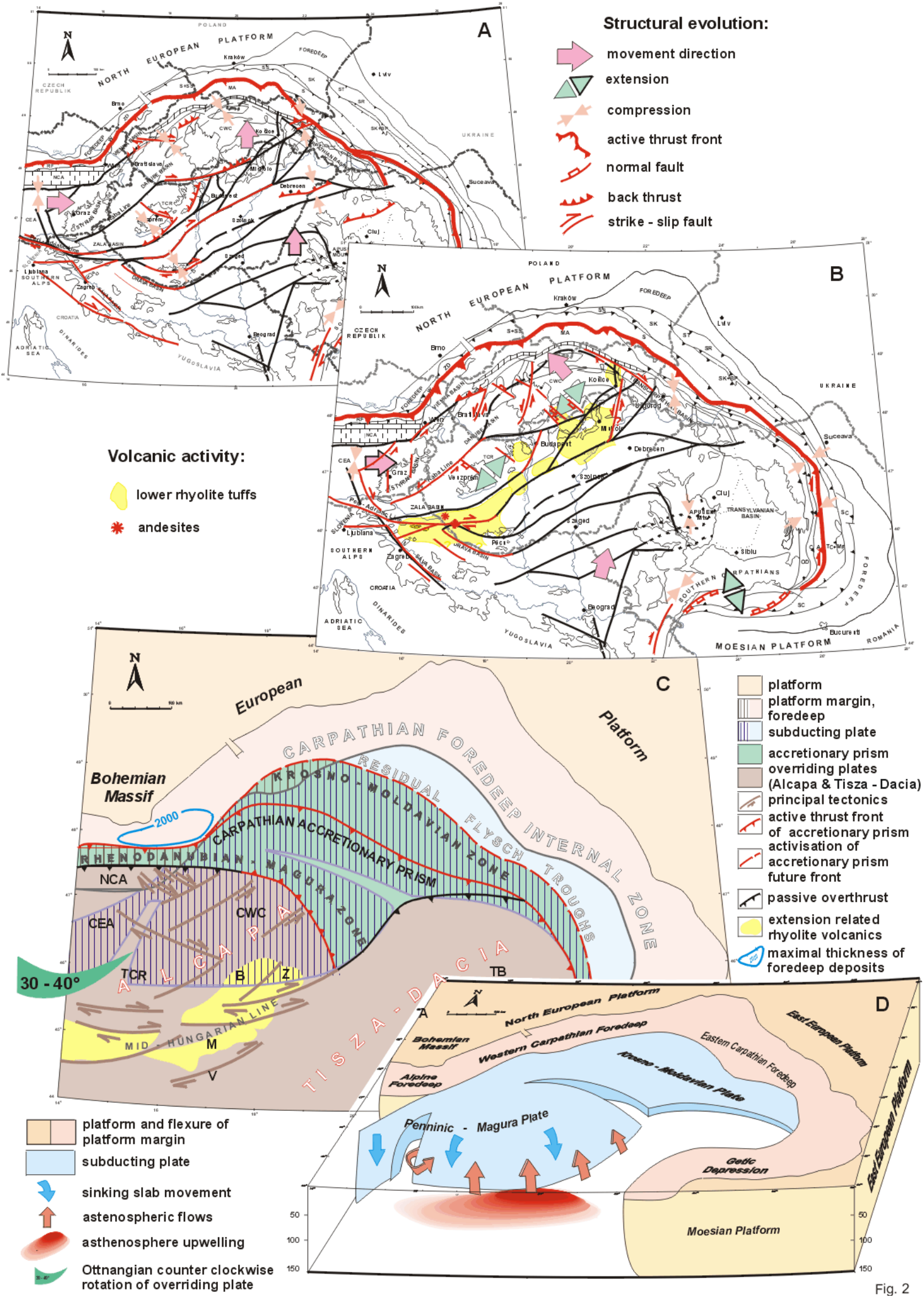

Fig. 2. Palinspastic reconstruction of the Carpatho-Pannonian region during the Early Miocene (Eggenburgian and Ottnangian). (a) - active faults during Eggenburgian; (b) - active faults and volcanic activity during Ottnangian; (c) - palinspastic reconstruction; (d) - block diagram showing the assumed position of subducted lithosphere slabs, compensating asthenosphere flows, and asthenosphere upwelling in the backarc domain. 
eastern segment of the arc (Nemčok et al., 1993).

Subduction in the eastern part of the Penninic-Magura realm is not directly evidenced by contemporaneous volcanic activity. However, it is indirectly evidenced by younger extension-related volcanics (which require a preceding subduction process for mantle enrichment). Absence of contemporaneous volcanic activity indicates either a low angle subduction or subduction under conditions of general and far reaching compression (e.g. Nemčok et al., 1998). This inference is supported by the Early Miocene palinspastic reconstruction (Fig. 2), in which the Western Carpathians are a part of the Alpine orogenic belt (Plašienka and Kováč, 1999).

Evolution of subduction processes in the KrosnoMoldavian realm is well recorded by inversion of the relevant basins as well as by the arc type basaltic andesite to andesite volcanic activity. The volcanic activity was shortlived creating just one generation of stratovolcanoes, extrusive domes and/or intrusions, with the exception of the segment between the Western and Eastern Carpathians, where two or three successive arcs have been identified (Lexa et al., 1993; Lexa and Konečný, 1998). The overall pattern of the volcanic arc shows that the volcanics are getting younger eastward (Pécskay et al., 1995). As the time of volcanic activity in the given segment of the Carpathians corresponds roughly to the last thrusting in the front of the accretionary prism in that segment (compare Figs. 4a, b-6a, b), the subduction zone was at the time of magma generation in its final stage of evolution or even in a state of lithosphere slab detachment. Their relative positions with respect to the trace of the former subuction zone (gravity minimum) indicate that the subducting slabs had reached a magma generation depth of 120-150 km (Ninkovich and Hayes, 1972) when they were almost vertical. The timing of volcanic activity implies also a division of the subducting Krosno-Moldavian slab into two major segments (corresponding roughly to northwestern and southeastern parts of the Eastern Carpathians).

In the northwestern part of the Eastern Carpathians (and the eastern part of the Western Carpathians) subduction started during Karpatian time (17.5-16.5 Ma) and the sinking slab reached magma generation depth during Late Badenian/Early Sarmatian time (14.0-12.5 Ma). Longer lasting volcanic activity with migration of the volcanic axis towards the subduction zone in the Transcarpathian basin realm (Lexa and Konečný, 1998) indicates a greater width of the subducted crust in this segment of the arc (around 200-300 km) and records the subduction zone verticalization from about 50 degrees at Early Sarmatian to about 70 degrees during Early Pannonian (11-9.5 Ma).

In the southeastern part of the Eastern Carpathians very short-lived arc type volcanic activity can be interpreted either as an indication of a limited width of the subducted crust (probably not over $200 \mathrm{~km}$ ) or even as an indication of detachment of the sinking slab from the platform margin during volcanic activity (Spakman et al., 1993; Nemčok et al., 1998). Subduction started during Late Badenian times (14.513.5 Ma) and the sinking slab had reached the magma generation depth, from the north progressively southward, dur- ing Late Pannonian to Pleistocene times (9-1 Ma). Progressive detachment of the sinking slab would explain the well known migration of volcanic activity, especially in the case of the Calimani-Ghurghiu-Hargita mountain range (Szakács and Seghedi, 1995; Linzer, 1996). The present day association of the last remnant of the sinking slab (Vrancea seismic zone) with the recent volcanic activity at the southern tip of Hargita confirms such a model.

\section{Asthenospheric upwelling (diapiric uprise) in space and time}

Areas of thinned crust and lithosphere corresponding to extensional back arc basins localize places of asthenospheric mantle upwelling during the Neogene. Their present position has been documented by thermal modeling, the former one is indirectly localized by spatial distribution of the areal type (extension-related) silicic and andesitic volcanism.

The areal type silicic volcanism started in the western part of the back arc basin during the Early Miocene. According to Pécskay et al. (1995), it is known from the area of northern Croatia and southwestern Hungary, as well as in northern Hungary (formerly one volcanic field separated by younger transform faulting; Csontos et al., 1992). The volcanism indirectly testifies that subduction of the Penninic-Magura slab eastern segment accelerated and steepened(?) during Late Eggenburgian-Ottnangian time (20-18 Ma) and that the related Early Miocene back arc transtension/extension coupled with the asthenospheric mantle upwelling took place relatively far behind the active orogenic front, in the hinterland of the Western Carpathians (Fig. 2c, d).

During the Karpatian and Early Badenian times areal type silicic volcanism was active in the area of northeastern Hungary and extended northeastward into the Transcarpathian basin. During the Middle Miocene, areal silicic volcanism was concentrated in the hinterland of the Eastern Carpathians (northeastern Hungary, Transcarpathian basin and Transylvanian basins; Pécskay et al., 1995). This type of volcanic activity indirectly testifies about the start of subduction in the Krosno-Moldavian flysch zone, which took place in the Karpatian/Early Badenian time (17-16 Ma) in the northwestern part of the Eastern Carpathians and during the Late Badenian/Early Sarmatian time (14-13 Ma) in the southeastern part of the Eastern Carpathians. The relevant Middle Miocene back arc extension was coupled with the diapiric uprise of asthenospheric mantle in the hinterland of the Eastern Carpathians (Fig. 3c, d and Fig. 4c, d).

Transtension and initial rifting of the back arc basin marked by the areal silicic volcanism was followed by a synrift stage coupled with the areal andesite volcanism and basin and range tectonics. Related crustal thinning and advanced diapiric uprise of asthenospheric mantle took place first in the western part of the back arc realm in the Styrian basin, Danube basin, Central Slovakia and Northern Hungary (Fig. 3d) during Karpatian - Early Badenian times (around 16.5 Ma) and continued in the Central Slovakia and Northern 


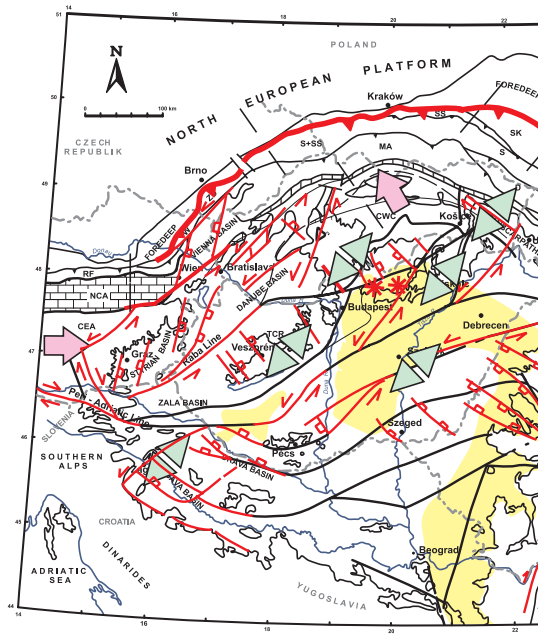

\section{KARPATIAN - EARLY BADENIAN}

Volcanic activity:

Middle rhyolite tuffs

Dej - Novoselice rhyolite tuffs

rhyolites

* andesites

* high-K to shoshonitic rocks

\section{Structural evolution:}

$\supset$ movement direction

$\Delta \nabla$ extension

4. compression

2 active thrust front

normal fault

7 strike - slip fault

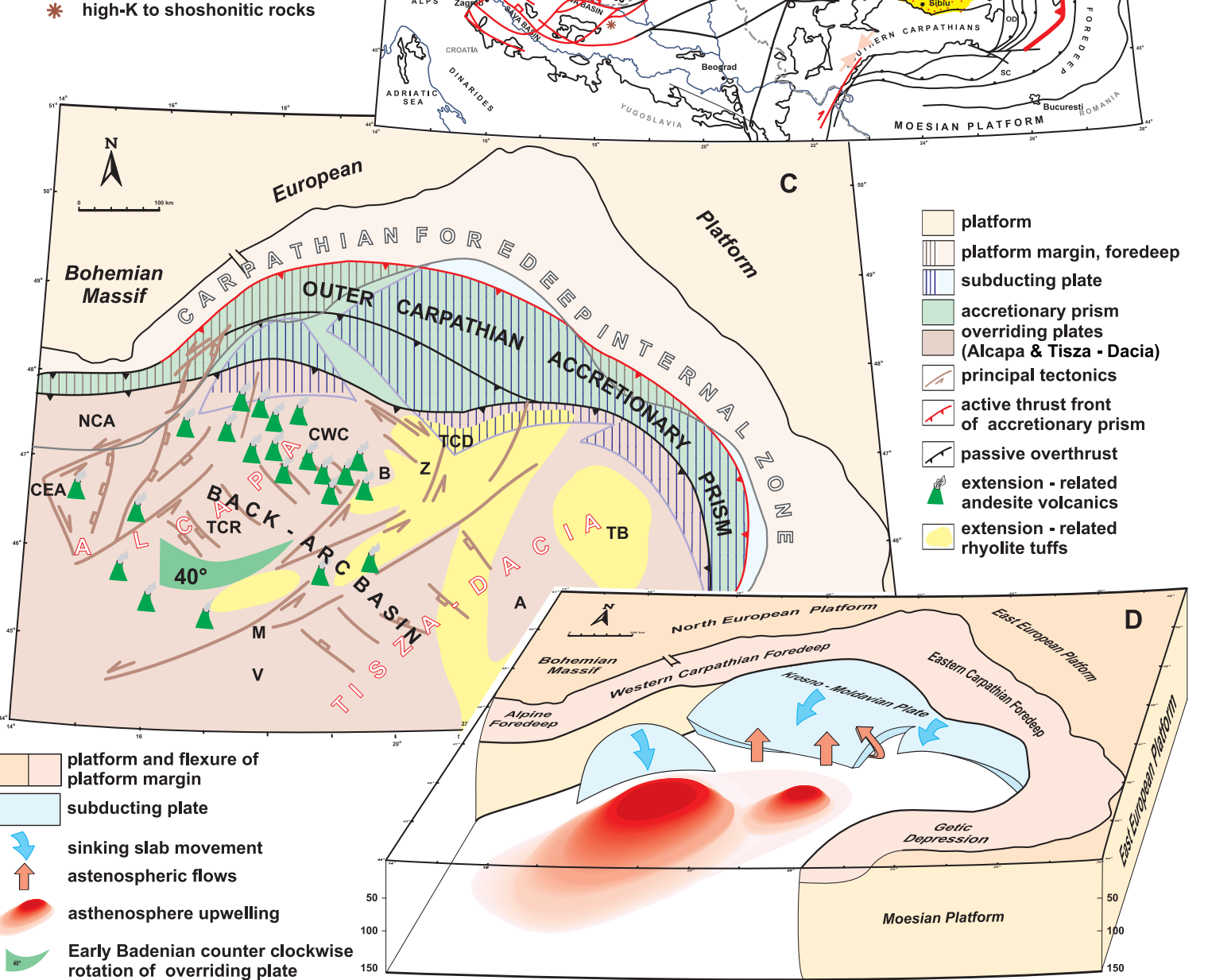

Fig. 3. Palinspastic reconstruction of the Carpatho-Pannonian region during the Early/Middle Miocene (Karpatian and Early Badenian). (a) - active faults and volcanic activity during Karpatian; (b) - active faults and volcanic activity during Early Badenian; (c) - palinspastic reconstruction; (d) - block diagram showing the assumed position of subducted lithosphere slabs, compensating asthenosphere flows, and asthenosphere upwelling in the back-arc domain. 
Hungary untill the Sarmatian times (12 Ma). In the eastern part of the Pannonian back arc basin, in the area of northeastern Hungary and the Apuseni mountain range (Fig. 4d), it took place during Late Badenian and Sarmatian times (14$11 \mathrm{Ma})$.

As discussed above, the areal type (extension-related) andesite volcanics (including shoshonites and adakites) indicate advanced stages of back arc diapiric uprise of asthenospheric mantle and hence they indirectly testify about advanced stages of subduction in the relevant segments of the Krosno-Moldavian flysch zone. According to Pécskay et al. (1995) the oldest volcanics of this type are of Otnangian age (around 19Ma) in the southwestern part of the Pannonian basin. Rather sporadically, there are also andesites of Karpatian age in the Danube basin and Mtra Mountains. Early Badenian (16.5-16.0 Ma) andesite volcanics are much more widespread in the $\mathrm{W}, \mathrm{SW}$ and NW parts of the Pannonian basin (including shoshonitic rocks in the Styrian basin). In northern Hungary and southern Slovakia volcanic activity continued till the Late Badenian - Early Sarmatian (around 14-13 Ma)(Pécskay, oral communication), while a longer lasting volcanic activity (untill the Early Pannonian, around $9 \mathrm{Ma}$ ) took place in the Central Slovakia Volcanic field (Konečný et al., 1995a). In the NE part of the Pannonian basin the areal type andesite volcanic activity started in Late Badenian times (around 14 Ma) and continued, including rocks of dacite composition, till Early Pannonian times (119.5 Ma), alternating with periods of silicic volcanism. (However, in this region separation of the areal and arc type andesite volcanics is questionable.) In the Apuseni Mountains areal type andesite volcanics erupted in several phases during Late Badenian to Early Pannonian timse (14.5-9.3 Ma). Late Pannonian (7.4 Ma) basaltic andesite occurrences near Detunata are the youngest in this region.

The stage of postrift thermal subsidence in the Pannonian back arc basin system (sensu Horváth, 1993) associated with alkali basalt volcanics. Sporadic and dispersed volcanic activity of alkali basalts took place in pulses (Pécskay et al., 1995): volcanic activity started in the Styrian basin and Great Hungarian Plain area during the Pannonian, then it continued in several episodes during the Pontian, Pliocene, and Pleistocene along the margins of the Transdanubian Central Range and at the northern margin of the Pannonian basin system (Novohrad basin), with a few Late Pliocene - Pleistocene occurences also in the southern part of the Transylvanian basin (Figs. 5, 6). As mentioned above, alkali basalt volcanism in the region reflects an extensional environment owing to continuing subduction in the eastern segments of the arc (Nemčok et al., 1998), local diapiric uprise in the asthenosphere with sufficient vertical displacement to generate alkali basalt magmas, and arrival and involvement of asthenosphere not affected by subduction processes, brought into the area probably by compensating asthenosphere flow.

\section{Neogene development of the Carpatho-Pannonian region-evidence connected with its structural evolu- tion}

The Oligocene - Early Miocene evolution (25-20 Ma) of the Carpatho-Pannonian region was governed initially by a northward drift of the Adriatic microplate, leading in the realm of the Eastern Alps to a collision of the orogene with the European platform margin (Fig. 2). This collision resulted in compressive thrust tectonics in the Eastern Alps and associated with the Rhenodanubian and Magura flysch belt formation (Tollman, 1966, Eliáš et al., 1990, Pereson and Decker, 1997). Development of the WNW-ESE right lateral strike slip zones in the Central Western Carpathians (Fig. 2; at present striking WSW-ENE due to $80-90^{\circ}$ counter-clockwise rotation, Márton and Kováč, 1998) can be considered as the first sign of fragmentation of the Eastern Alpine - Western Carpathian lithosphere (initiation of a future Alcapa microplate). These shear zones compensated movement of the Eastern Alps northward and their origin preceded lateral extrusion of the Alcapa lithospheric fragment into the Carpathian realm (Plašienka and Kováč, 1999; Kováč, 2000).

Collision and steepening of the subducted plate in front of the Eastern Alps resulted in flexural bending and rapid subsidence of the platform margin, recorded by a thick pile of corresponding autochthonous molasse deposits in a foredeep at the boundary of the Eastern Alps and Western Carpathians (Fig. 2c; Jiříček and Seifert, 1990).

The Eggenburgian to Ottnangian (20-18 MA) active thrust front of the Carpathian accretionary prism was formed in the north by nappes of the Magura and Dukla units (Kováč et al., 1998, Kováč, 2000). A back-thrusting of the Pieniny Klippen belt elements over the front of the Central Carpathians and related folding of the Paleogene sediments took place at the same time on the internal side of the accretionary wedge (Plašienka et al., 1998), indirectly suggesting that the subducting microplate was represented by lithosphere formerly underlying the Magura nappe (Fig. 2c).

The Alcapa escape started during the Ottnangian (1817.5 Ma; (Ratschbacher et al., 1991a, 1991b; Pereson and Decker, 1997). Further drift of the microplate was controlled by continuing subduction rollback in front of the Carpathians. A tear between the Rhenodanubian and Magura flysch basement accelerated sinking of the easternmost segment of the Peninnic-Magura plate (Kováč, 2000). An oblique collision of the Alcapa microplate with the European platform margin (Bohemian massif) resulted in the $40-50^{\circ}$ counterclockwise rotation of the Western Carpathian segment at the end of the Ottnangian (Márton et al., 1995, 1996; Kováč and Túnyi, 1995; Kováč et al., 1998; Krs et al., 2000).

Structural evolution of the early "Pannonian back arc basin" was dominated by an extensive drift of the unamalgamated microplates Alcapa and Tisza-Dacia, accompanied locally by transpression and/or transtension. The occurrence of the Eggenburgian - Ottnangian silicic volcanics at the SE edge of the Alcapa microplate and at the NW edge 


\section{LATE BADENIAN - SARMATIAN}

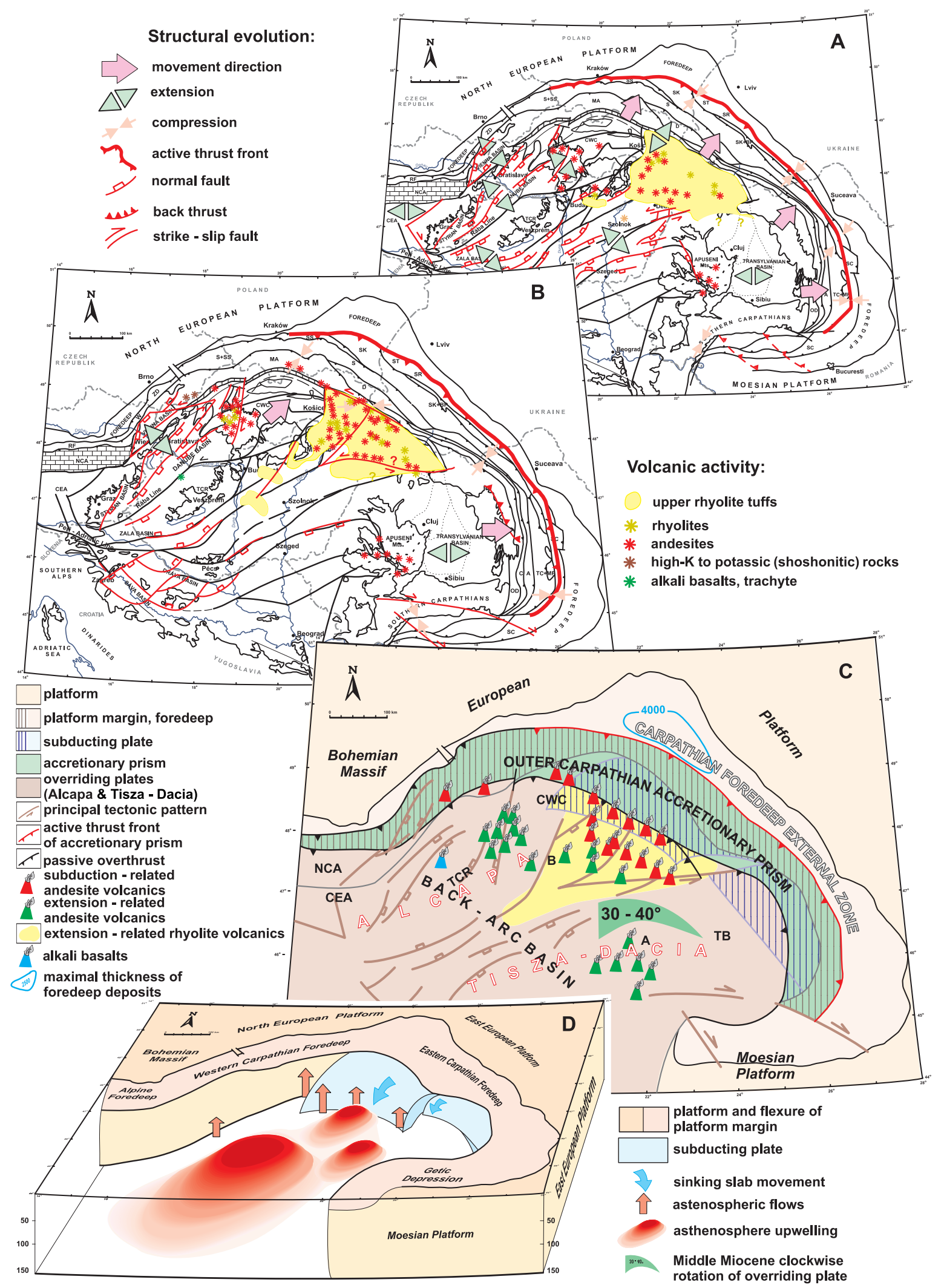

Fig. 4. Palinspastic reconstruction of the Carpatho-Pannonian region during the Middle Miocene (Late Badenian and Sarmatian). (a) - active faults and volcanic activity during Late Badenian; (b) - active faults and volcanic activity during Sarmatian; (c) - palinspastic reconstruction; (d) - block diagram showing the assumed position of subducted lithosphere slabs, compensating asthenosphere flows, and asthenosphere upwelling in the back-arc domain. 
of the Tisza-Dacia plate points to an extensive right-lateral displacement along the SW-NE trending transform fault of the "Mid-Hungarian line" (e.g. Bergerat, 1989; Nagymarosi, 1990; Csontos et al., 1991, 1992; Fodor, 1992; Kováč et al., 1994). Volcanic activity took place in a terrestrial or shallow marine environment indicating a relatively thick crust and initial subsidence in transtension zones (Fig. 2b, c).

During the late Early Miocene and early Middle Miocene (17.5-15 Ma) subduction of the former Magura flysch basment reached the stage of detachment. Evolution of the Carpatho-Pannonian region was dominated mostly by a further subduction rollback at the orogenic front of the next segment (Fig. 3; Kováč et al., 1998; Kováč, 2000). Tension in the subducting plate, involving now lithosphere underlying formerly the Krosno nappes (Royden et al., 1993a, b), caused widespread stretching in the overriding, partially amalgamated microplates Alcapa and Tisza-Dacia (Csontos, 1995), expressed in the synrift stage of the back arc basin system (Horváth, 1993).

The active front of the accretionary prism moved during this time interval to the front of the Waschberg-Žadnice, Pouzdøany, Subsilesian/Silesian, Skole, Skiba and Tarcau nappe groups, thrusted over sediments of the internal parts of the foredeep which had been deposited on slopes of the European platform (Fig. 3a, Jiř́iček, 1979; Roth, 1980; Kováč et al., 1989, 1998; Oszczypko, 1996; Sandulescu, 1988; Matenco, 1998). These units were incorporated in the upper plate and their former basement was added to the sinking plate.

The final subsidence of the detached lithosphere fragment, representing the former basement of the Magura nappe (the eastern segment of the Peninnic-Magura plate) and the initial stage of subduction in the outer Krosno-Moldavian flysh basins, limited at this time to its northwestern part (Fig. 3c, d), accelerated lateral extrusion of the Alcapa microplate from the East Alpine collision zone. The northward drift of the Alcapa microplate was marked at its NW side by a system of left-lateral transform faults responsible for initial opening of the Vienna Basins by a pull-apart mechanism (Royden, 1988; Fodor, 1995; Kováč et al., 1997).

Steepening and detachment of the Magura nappe basement is proven indirectly by a temporary fast subsidence in the western segment of the Carpathian foredeep during the Karpatian, followed by a rebound during the Middle Late Badenian (Kováč et al., 1989, 1998; Tomek and Hall, 1993; Meulenkamp et al., 1996). Docking of the Alcapa microplate in the European platform margin owing to the Krosno-Moldavian plate subduction roll-back was a reason for the following $30^{\circ}$ counter-clockwise rotation of the Western Carpathians at the end of the Early Badenian (Túnyi and Kováč, 1991; Kováč and Túnyi, 1995; Márton et al., 1992, 1995; Túnyi and Márton, 1996; Kováč and Márton, 1998).

Tectonic evolution of the Pannonian basin realm was at the same time dominated by extensive stretching. Unroofing of the lowermost tectonic elements (Penninicum, Vahicum, Inacovce-Kritschevo unit) took place in the western and eastern parts of the Alcapa microplate (Tari et al., 1992; Horváth,
1993; Soták et al., 1993; Plašienka, 1995; Plašienka et al., 1997; Baráth et al., 1997). Rifting in the western part of the Alcapa microplate leading to the evolution of the Styrian and Danube basins was accompanied by extension-related andesite (shoshonitic andesite) volcanic activity (Ebner and Sachsenhofer, 1995; Pécskay et al., 1995). Related stretching during the Karpatian and Early Badenian time has been estimated at $80 \mathrm{~km}$ (Tari and Horváth, 1995).

While back arc extension in the western part of the Pannonian back arc basin reached during Karpatian to Early Badenian times its advanced stage, in the eastern part of the Pannonian basin it was in an initial stage, accompanied by Early Badenian silicic volcanic activity (Fig. 3b, c). Zones of active extension and volcanic activity localize areas of the asthenosphere uprise. Hence we may conclude that during Karpatian and Early Badenian times an intense diapiric uprise of asthenosphere took place in the area of the Styrian and Danube Basins (Figs. 2d, 3d), while an initial stage of asthenosphere uprise (upwelling) is assumed in the areas of NE Hungary and N Romania. These processes corresponded to the advanced and initial stages, respectively, of subduction of the northwestern and southeastern segments of the Krosno-Moldavian plate (Fig. 3d)

During the Middle Miocene time (15-11.5 Ma) the evolution of the Carpatho-Pannonian region was still dominated by subduction at the orogenic front and diapiric uprise of asthenospheric mantle in the back arc region (Fig. 4).

The Middle to Late Badenian active front of the accretionary prism was represented by overthrust of the Subsilesian/Silesian nappe over sediments of the external part of the foredeep at the northern part of the Carpathian arc (Fig. 4a). In the eastern part of the Carpathian arc overthrusting of the Skole-Skiba-Tarcau nappes over the Borislav-Pokuty and Marginal Folds zones activated folding in the internal part of the foredeep, which was finally accreted as the SamborRozniatov and Folded Neogene Molasse units (Oszczypko and Slaczka, 1989; Sandulescu, 1988; Matenco, 1998; Kováč et al., 1998). Compression in the accretionary prism reflects the Badenian and later Sarmatian tectonic phases (Sandulescu, 1988; Oszczypko and Slaczka, 1989; Oszczypko, 1997). Coupling to the subducting plate retreating northeastward in front of the Alcapa microplate and eastward in front of the Tisza-Dacia microplate, caused a continuous intense stretching in overriding microplates (Royden, 1993a, b, Csontos, 1995, Kováč et al., 1998). The back arc realm was dominated by the synrift evolutionary stage of extensional basins in the western as well as eastern parts (e.g. Vienna, Danube, Transcarpathian basins, early rifts of Apuseni Mountains, etc.) and by a general uplift in the area of the Great Hungarian Plain basins during the Sarmatian (Meulenkamp et al., 1996).

The Middle Miocene evolution of the Carpathian arc and related back arc basins documents not only compensation of the subduction rollback by diapiric uprise of asthenospheric mantle in the back arc realm, but at the same time it documents also a segmentation of the arc, by the contrasting evo- 


\section{PANNONIAN}

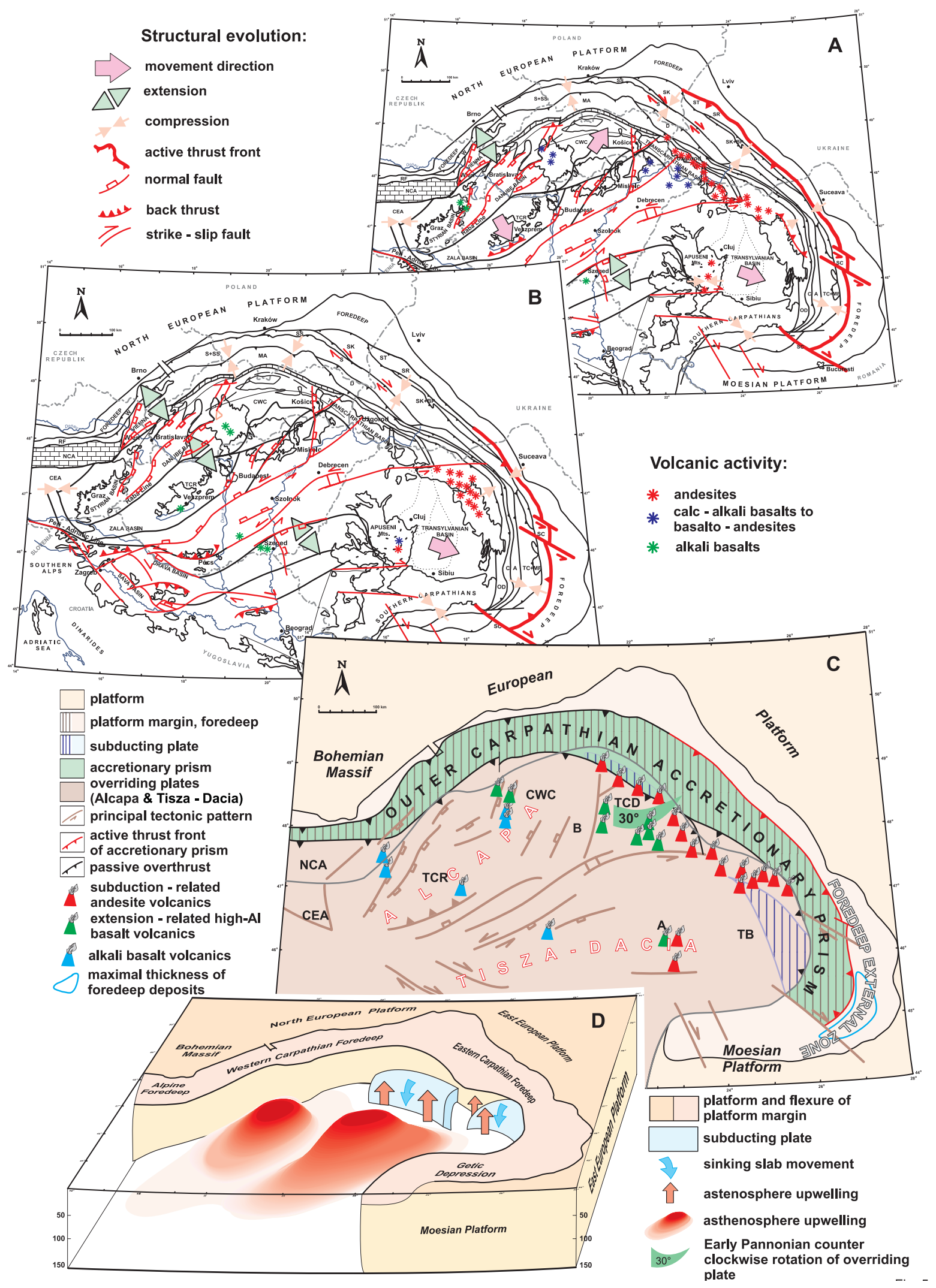

Fig. 5. Palinspastic reconstruction of the Carpatho-Pannonian region during the Late Miocene (Pannonian). (a) - active faults and volcanic activity during Early Pannonian; (b) - active faults and volcanic activity during Late Pannonian; (c) - palinspastic reconstruction; (d) - block diagram showing the assumed position of subducted lithosphere slabs, compensating asthenosphere flows, and asthenosphere upwelling in the back-arc domain. 
lution in the Western Carpathians, NW part of the Eastern Carpathians and SE part of the Estern Carpathians.

In the West, the final amalgamation of the Western Carpathians to the platform is documented by the gradual collision of the Alcapa microplate with the continental margin from the SW towards the NE, as well as by timing of core mountain uplifts using results of fission track dating (Jiříček, 1979; Kováčet al., 1994). The stretching related to the diapiric uprise of asthenospheric mantle (sensu Huismans et al., 1996) in the western part of the Pannonian basin resulted in the NW-SE oriented extension (Fig. 4a, b, Kováč et al., 1993; Lankreijer et al., 1995; Lankreijer, 1998).

In front of the NW part of Eastern Carpathians (Western/Eastern Carpathians boundary), thrusting of the Subsilesian/Silesian and Skola nappes over the external part of the foredeep was concluded in the Sarmatian. The observed narrowing of the subduction related compression zone (accretionary prism of the Outer Carpathians) and corresponding approach of extensional basins closer to the rear of the accretionary prism (Transcarpathian depression) reflected steepening of the subduction zone preceding the final detachment of the subducted slab (Tomek and Hall, 1993; Nemčok et al., 1998). This fact can be proven indirectly by a rapid Late Badenian - Sarmatian subsidence in the foredeep on the Western - Eastern Carpathian boundary (Fig. 4c) due to deep subsurface load (Kryziviec, 1997), followed by a fast rebound after the final detachment of the subducted slab during the Early Pannonian (Meulenkamp et al., 1996).

In the East, continuing subduction in the Eastern Carpathians resulted in NE-SW and E-W oriented extension in the eastern part of the Pannonian basin, including the Apuseni Mountains (Huisman et al., 1996; Kováč et al., 1998). Thrust activity continued, the active front of the accretionary prism of the Moldavide nappes being represented by overthrusting of the Folded Neogene Molasse unit over the external part of the foredeep (Matenco, 1997). The retreating subduction zone and related thrusting in the southeastern part of the Eastern Carpathians during the Sarmatian was compensated on the boundary of the Eastern and Southern Carpathians by an extensive right-lateral transform fault system (Ratschbacher et al., 1993; Linzer, 1996; Matenco, 1997).

Middle to early Late Miocene development of the eastern part of the Pannonian back arc basin realm documents movement of lithospheric fragments confirmed by results of paleomagnetic measurements. The southern microplate (TiszaDacia) rotated during this time about $60^{\circ}$ clockwise and up to $30^{\circ}$ counter-clockwise rotation was recorded in the Sarmatian rocks in the eastern part of the Alcapa microplate (Transcarpathian superunit) (Panaiotu, 1998; Kováč and Márton, 1998; Márton et al., 2000).

Geodynamic evolution of the Carpatho-Pannonian region during the Late Miocene time (11.5-7 Ma) was marked by the end of subduction in the northwestern part of Eastern Carpathians and by related lithosphere slab detachment (Tomek and Hall, 1993), while subduction continued in the southeastern part of Eastern Carpathians (Fig. 5). A transition from active rifting to the postrift thermal subsidence reflects a corresponding change in the western and central parts of the Pannonian back arc basin system (Horváth, 1993; Csontos and Horváth, 1995; Meulenkamp et al., 1996; Kováčet al., 1998).

The active front of the accretionary prism during the Late Miocene and Pliocene time was represented by Folded Neogene Molasse thrusted over sediments of the external zone of the foredeep (Sandulesu, 1988; Matenco, 1997). Active thrusting and subduction were limited to the southeastern part of Eastern Carpathians (Fig. 5a, b), on both sides bounded by active transform fault systems, visible quite well even in the recent morphology (Matenco, 1997). The youngest movements at the southern tip of the Eastern Carpathians are of Late Pliocene to Pleistocene ages. The great thickness of the Late Pliocene and Pleistocene sediments in front of the accretionary prism (due to deep subsurface load), affected recently by a rebound, points to a recent lithosphere slab detachment, still observable in the Vranca seismic zone (Constantinescu and Enescu, 1984; Tomek and Hall, 1993; Meulenkamp et al., 1996; Nemčok et al., 1998).

Evolution of the Pannonian basin realm was differentiated. In the western and central parts of the basin uplift and second rifting took place, followed by a long lasting thermal subsidence (Lankreijer, 1998). The uplift reflected most probably a collision of the arc with the European platform in the northeastern sector of the Carpathian arc (Sanders, 1999). Local extension (rifting) was related to continuing subduction in the southestern part of Eastern Carpathians. Evolution of extensional basins compensating subduction rollback continued especially in the eastern part of the Transylvanian basin.

The Late Miocene to Pliocene evolution of the CarpathoPannonian region points clearly to coupling of the subduction rollback and back arc diapiric uprise of asthenospheric mantle (Fig. 5d). The end of subduction processes was immediately reflected in a transition from rifting to thermal subsidence especially in the eastern part of the back arc realm (Fig. 6). In the western part tectonic inversion dominated (Horváth and Cloetingh, 1996).

\section{Mutual relationship of the subduction and back-arc asthenospheric mantle upwelling}

It follows from the preceding review, that the Tertiary evolution of the Carpathian-Pannonian system was governed by gravity driven subduction of lithosphere underlying former flysch basins. Subduction took place progressively from the west eastward in three segments. Evolution of subduction in each one of the segments followed roughly the same scheme: once a hinge of the migrating subduction zone reached the continental margin, the early stage of subduction rollback was followed by the verticalization of the subduction zone and final detachment (Royden, 1993b).

Evolving subduction in each one of the three segments was compensated locally by asthenospheric mantle upwelling in the back arc realm, as far as $250 \mathrm{~km}$ from the active arc. It is important to note that the back arc lithosphere stretching was 


\section{PONTIAN - PLEISTOCENE}

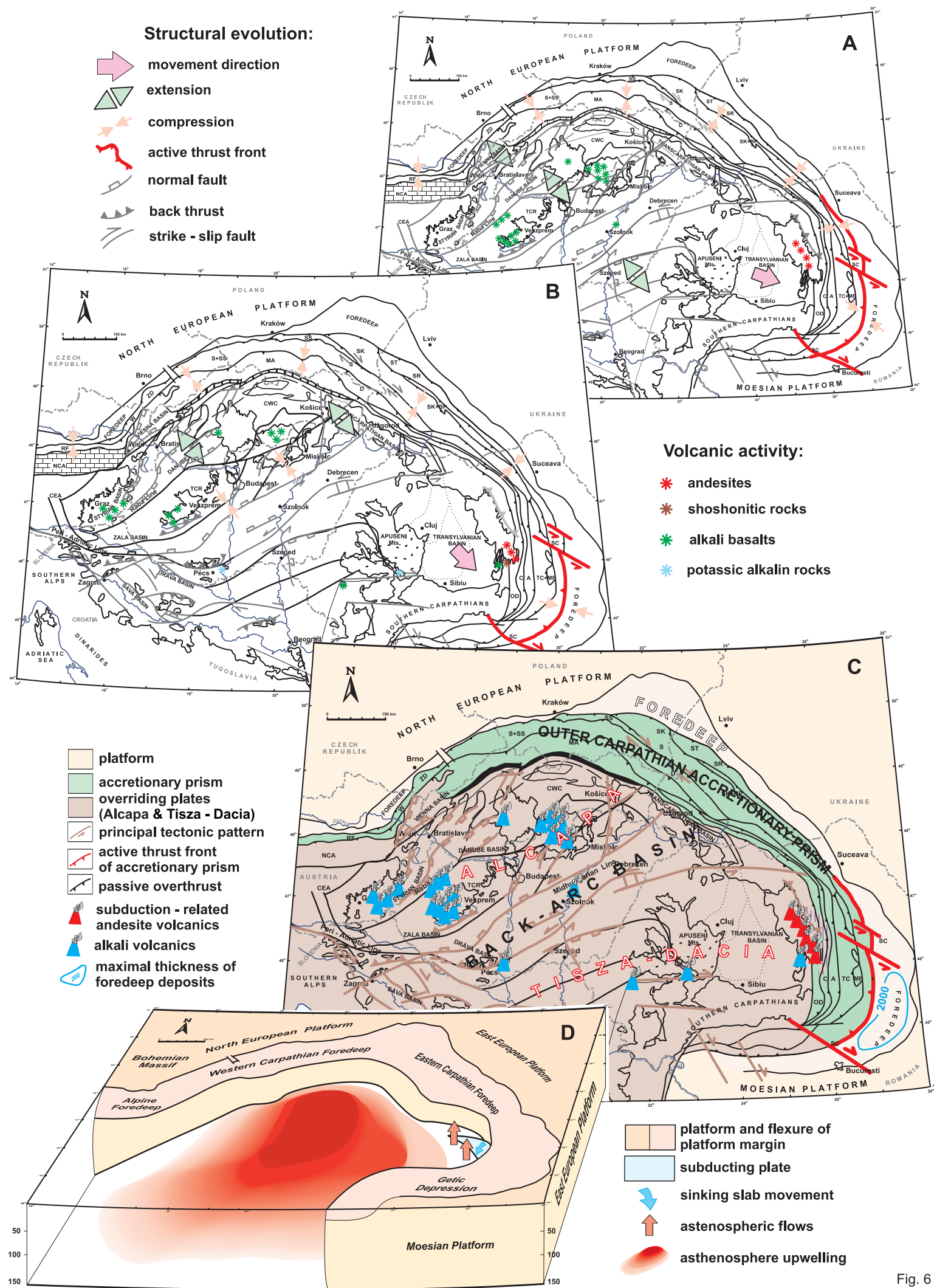

Fig. 6. Palinspastic reconstruction of the Carpatho-Pannonian region during the Late Miocene to Quaternary (Pontian to Pleistocene). (a) active faults and volcanic activity during Pontian; (b) - active faults and volcanic activity during Pliocene and Pleistocene; (c) - palinspastic reconstruction; (d) - block diagram showing the assumed position of subducted lithosphere slabs, compensating asthenosphere flows, and asthenosphere upwelling in the back-arc domain. 
not uniform, but rather it concentrated into zones of intense stretching separated by less affected blocks. In such a case the zones of intense stretching are connected by a system of transform faults. Timing of the asthenospheric mantle upwelling closely followed the evolution of subduction in the relevant segment of the arc.

Subduction and asthenospheric mantle upwelling in the back-arc realm represent mutually interrelated processes. Driving forces were provided by a gravitational instability of "oceanic" lithosphere resting over asthenosphere of lesser density (e.g. Elasser, 1971; Jischke, 1975; Yokohura, 1981; Willeman and Davies, 1982). To explain their relationship one has to introduce the concept of asthenospheric mantle flow, compensating for gravity driven subduction involving a large scale subsidence of the higher density lithospheric slab (Dvorkin et al., 1993; Nurr et al., 1993; Royden, 1993b). Because asthenosphere behaves in response to longterm stresses like a viscous liquid, the whole system is in a metastable condition and overlying "oceanic" lithosphere tends to submerge. However, this process involves an exchange of space and hence requires a free passage for related asthenospheric counterflow - either under the sinking slab (bottom flow) or at the sides of the sinking slab (side flow). The asthenosphere bottom flow is rather ineffective, resulting in very low subduction rates. It is the asthenospheric side flow which provides for the fast enough exchange of space, its speed being controlled by the size of the submerging plate segment, differential density, and the effective viscosity of surrounding asthenosphere. In the case of the Carpathian arc, confining continental lithosphere represented an obstacle for the asthenospheric "sideflow" to take place. However, evolution of the accretionary prism, back arc extensional basins, and andesite volcanic activity testify about the division of the subducting slab at least into three major segments separated by deep reaching tears, allowing the asthenospheric "sideflow" to take place around edges of the microslabs. These segments (microslabs) correspond roughly to the Western Carpathians, northwestern part of the Eastern Carpathians, and southeastern part of the Eastern Carpathians.

\section{Conclusions}

\section{Conclusions}

Analysis of geophysical, geological, petrological, and structural data points towards the present models, in which the Tertiary evolution of the Carpathian arc and Pannonian basin is interpreted in terms of the coupled system of: (1) Alpine (A-type) subduction and compressive orogene belt development due to compression by the Adriatic microplate, (2) lateral extrusion of the Alcapa lithosphere from the Alpine collision assisted by transform faults, (3) Carpathian gravity-driven (B-type) subduction of oceanic or suboceanic lithosphere underlying former flysch basins and (4) back arc extension associated with the diapiric uprise (upwelling) of asthenospheric mantle.
Though the subduction and related asthenospheric mantle upwelling were always contemporaneous in any given segment of the Carpatho-Pannonian system they did not take place at the same time in the whole system. Rather, we observe a progression from the west eastward. Here are the main features:

- The Neogene evolution of the Carpathian arc was driven by subduction of lithosphere underlying flysch basins, in three stages: (1) Late Oligocene to Early Miocene subduction of the remnant oceanic lithosphere of the internally situated Peninnic-Magura flysch zone basement - the corresponding suture zone follows the contact of the Pieniny Klippen Belt with internal Magura units (Kováč et al., 1994); (2) late Early Miocene to Sarmatian and (3) Pannonian to Pliocene subduction of suboceanic(?) lithosphere of the externally situated KrosnoMoldavian flysch zone basement - the corresponding suture zone follows the subsurface contact of the European plaform with Carpathian elements, its approximate position being indicated by the axis of the gravity low following the Carpathian arc (Tomek et al., 1989; Tomek and Hall, 1993).

- Related contrasting evolution of the accretionary prism, as well as timing of initial inversion in the Outer Carpathian flysch basins and final thrusting of the accretionary prism over foredeep sediments, makes it possible to distinguish three segments with a different history of subduction, roughly corresponding to the Western Carpathians, northwestern part of Eastern Carpathians, and southeastern part of Eastern Carpathians.

- The timing and spatial distribution of the arc-type (subduction-related) andesite volcanics indicate that subduction processes were halted by verticalization of the subduction zone, followed closely by detachment of the sinking lithosphere slab from the continental margin (Figs. 2d-6d). Final detachment of the sinking lithosphere fragments is confirmed by results of seismic tomography (Vortel and Spakman, 1992). Lithosphere detachment in progress is indicated by the interpretation of the Vrancea seismic zone at the southern tip of the Eastern Carpathians (Constantinescu and Enescu, 1984; Sperner et al., 2001).

- The generally short-lived volcanic activity of the arctype (subduction-related) andesite volcanics is interpreted either as an indication of a limited width of the subducted lithosphere (300-200 km in the NW segment of the Krosno-Moldavian zone and less than $200 \mathrm{~km}$ in the SE segment of the zone) or as an indication of the progressive detachment of the sinking slab from the platform margin during the volcanic activity.

- The time interval of 8-10 Ma between the initial stage of subduction and onset of the arc type basaltic andesite to andesite volcanic activity along the Carpathian arc suggests an average subduction rate of $1.5-2.5 \mathrm{~cm}$ 
a year. This estimate falls on the lower limit of rates $(2-25 \mathrm{~cm} /$ year) derived by model hydrodynamic calculations (Nurr et al., 1993) for a microplate of oceanic lithosphere $70 \mathrm{~km}$ thick, $500 \mathrm{~km}$ wide, and $500 \mathrm{~km}$ long. The low subduction rate implies obstacles for the compensating asthenosphere flow, perhaps represented by confining thick lithosphere on the NW and SE sides of the arc (the Bohemian massif and Moesian platform).

- Subduction in the Outer Carpathian flysch basin was since its beginning compensated by asthenospheric mantle upwelling (diapiric uprise) and related rifting in the back arc realm. Spatial distribution and timing of back-arc basins reflected the segmentation of sinking slabs, as well as the final verticalization of subduction zones. This segmentation should be understood as a gravity driven process allowing for asthenospheric side flow to take place and hence to speed up gravity driven overturn (subduction).

- Areas of thinned crust and lithosphere corresponding to the Neogene extension basins localize places of the diapiric uprise of asthenospheric mantle. Its position is documented also by thermal modelling and by the spatial distribution of the areal type (extension-related) silicic and andesitic volcanism (Figs. 2a, b-6a, b). Diapiric uprise of asthenospheric mantle started in the West following subduction in front of the Western Carpathians in Early Miocene times, then continued towards the northeast following subduction in front of the NW part of the Eastern Carpathians in Early / Middle Miocene times, and finally it affected central and eastern regions during Middle / Late Miocene times following initiation of subduction in the front of the SE part of the Eastern Carpathians.

- Late stage alkali basalt volcanics testify that during the late stage of back arc basin evolution extensional environments persisted (before the final tectonic inversion) and that the diapiric uprise of asthenospheric mantle incorporated unmetasomatized mantle material, perhaps brought into the area of the diapiric uprise by compensating asthenospheric mantle counterflows.

Acknowledgement. The authors are grateful to Dr. Csontos, whose valuable comments as a reviewer helped us to improve the presentation of our ideas and to Dr. G. G. Goles, who improved our use of the English language. The work was carried out using financial support of the Slovak VEGA grant agency-grants No. 1/7087/20, 2/7215/20 and 2/7068/20 and Ministry of Environment of the Slovak Republic-project Tectogenesis of the West Carpathian basins.

\section{References}

Balla, Z.: Neogene volcanites in the geodynamic reconstruction of the Carpathian region, Geophys. Trans., 26, 5-43, 1980.

Balla, Z.: Neogene volcanism of the Carpatho-Pannonian region, Earth evolution sciences, 3-4, 240-248, 1981.
Balla, Z.: The Carpathian loop and the Pannonian basin: a kinematic analysis, Geophys. Trans., 30, 4, 313-353, 1984.

Balla, Z.: Tertiary paleomagnetic data for the Carpatho-Pannonian region in the light of Miocene rotation kinematics, Tectonophysics, 139, 67-98, 1987.

Baráth, I., Kováč, M., Soták, J., and Lankreijer, A.: Tertiary collision, metamorphism and basin forming processes in the Eastern Slovakia (central Western Carpathians), in: Grecula et al. (Eds.): Geological evolution of the Western Carpathians, Mineralia slovaca, Monograph, 65-79, 1997.

Bergerat, F.: From pull-apart to the rifting process: the formation of the Pannonian basin, Tectonophysics, 197, 271-280, 1989.

Bezák, V., Šefara, J., Bielik, M., and Kubeš, P.: Models of the Western Carpathian lithosphere, in: Grecula, P., Hovorka, D. and Putiš, M. (Eds.): Geological evolution of Western Carpathians, Mineralia Slovaca-Monograph, Bratislava, 25-34, 1997.

Bielik, M.: Estimation of the effective elastic thickness and flexure rigidity in the Western Carpathians, Contr. Geophis. Instit. Slov. Acad. Sci., 25, 81-93, 1995.

Bielik, M., Bezák, V., Zeyen, H., Lankreijer, A., and Šefara, J.: New trends in the Western Carpathian lithosphere research, Mineralia Slovaca, 32, 165-168, 2000.

Boccaletti, M., Manetti, P., and Peltz, S.: Evolution of the Upper Cretaceous and Cenozoic magmatism in the Carpathian arc: geodynamic significance, Mem. Soc. Geol. It., 12, 267-277, 1973.

Buryanov, V. G., Gordiyenko, V. V., and Zavgorodnaya, O. V.: Geologičeskij model tektonosfery Evropy, Nauk, Dumka (Kyjev), 83, 3-16, 1987.

Constantinescu, L. and Enescu, D.: A tentative approach to possibly explaining the occurrence of the Vrancea earthquakes, Rev Roum. Geol. Geophys. et Geogr., Geophys., 28, 19-32, 1984.

Csontos, L., Tari, G., Bergerat, F., and Fodor, L.: Evolution of the stress fields in the Carpatho-Pannonian area during the Neogene, Tectonophysics, 199, 73-91, 1991.

Csontos, L., Nagymarosy, A., Horváth, F., and Kováč, M.: Tertiary evolution of the intra-Carpathian area: a model, Tectonophysics, 208, 221-241, 1992.

Csontos, L.: Tertiary tectonic evolution of the intra-Carpathian area: a review, Acta Vulcanologica, 7, 1-13, 1995.

Csontos, L. and Horváth, F.,: Tertiary structural evolution of the intra-Carpathian area: a report on integrated basin studies Pannonian Basin E. C. Project, Geol. Soc. Greece, Sp. Publ., 4, Proceedings of the XV Congress of the Carpatho-Balcan Geol. Ass., 12-17, 1995.

Dobosi, G., Fodor, R. V., and Goldberg, S. A.: Late-Cenozoic alkali basalt magmatism in Northern Hungary and Slovakia: petrology, source compositions and relationship to tectonics, Acta Volcanologica, 7, 199-208, 1995.

Downes, H., Pantó, Gy., Póka, T., Mattey, D. P., and Greenwood, P. B.: Calc-alkaline volcanics of the Inner Carpathian arc, Northern Hungary: new geochemical and oxygen isotopic results, Acta Volcanologica, 7, 29-42, 1995a.

Downes, H., Seghedi, I., Szakács, A., Dobosi, G., James, D. E., Vaselli, O., Rigby, I. J., Ingram, G. A., Rex, D., and Pecskay, Z.: Petrology and geochemistry of late Tertiary / Quaternary mafic alkaline volcanism in Romania, Lithos, 35, 65-81, 1995b.

Downes, H.: Neogene magmatism and tectonics in the CarpathoPannonian region, Mitt. Ges. Geol. Bergbaustud. Österr., 41, 104-105, 1996.

Dvorkin, J., Nur, A., Mavko, G., and Ben-Avraham, Z.: Narrow subducting slabs and the origin of the back arc basins, Tectonophysics, 227, 63-79, 1993. 
Ebner, F. and Sachsenhofer, R. F.: Paleogeography, subsidence and thermal history of the Neogene Styrian Basin (Pannonian basin system, Austria), Tectonophysics, 242, 133-150, 1995.

Elasser, W. M.: Sea floor spreading as thermal convection, J. Geophys. Res., 76, 1101-1112, 1971.

Eliáš, M., Schnabel, W., and Stráník, Z.: Comparison of the Flysch Zone of the Eastern Alps and the Western Carpathians based on recent observations, in: Minaříková, D. and Lobitzer, H. (Eds.): Thirty years of geological cooperation between Austria and Czechoslovakia, Geological Survey, Prague, 37-46, 1990.

Embey-Isztin, A., Downes, H., James, D. E., Upton, B. G. J., Dobosi, G., Ingram, G. A., Harmon, R. S., and Scharbert, H. G.: The petrogenesis of Pliocene alkaline volcanic rocks from the Pannonian Basin, Eastern Central Europe, J. of Petrology, 34, 317-343, 1993.

Fodor, L.: Late Paleogene tectonics and sedimentation in the Buda and Gerecse Hills - detailed studies as a basis for a working model of the entire Bakony Unit, Terra Abstr., 4, 21-22, 1992.

Fodor, L.: From transpression to transtension: Oligocene-Miocene structural evolution of the Vienna basin and the East Alpine - Western Carpathian junction, Tectonophysics, 242, 151-182, 1995.

Grove, T. L. and Kinzler, R. J.: Petrogenesis of andesites. Ann. Rev. Earth Planet. Sci., 14, 417-454, 1986.

Gyarmati, P.: The intermediate volcanism in the Tokaj Mts, Ann. Hung. Geol. Inst., 58, 195p, 1977.

Harangi, Sz., Vaselli, O., Tonarini, S., Szabó, Cs., Harangi, R., and Coradossi, N.: Petrogenesis of Neogene extension-related alkaline volcanic rocks of the Little Hungarian Plain Volcanic Field (Western Hungary), Acta Volcanologica, 7, 173-188, 1995.

Hawkesworth, C., Turner, S., Gallagher, K., Hunter, A., Bradshaw, T., and Rogers, N.: Calc-alkaline magmatism, lithospheric thinning and extension in the Basin and Range, J. Geophys. Res., 100, B7, 10 271-10 286, 1995.

Horváth, F.: Towards a mechanical model for the formation of the Pannonian basin Tectonophysics, 226, 333-357, 1993.

Horváth, F.: Phases of compression during the evolution of the Pannonian basin and its bearing on hydrocarbon exploration, Marine and Petroleum Geology, 12, 837-844, 1995.

Horváth, F. and Cloetingh, S.: Stress-induced late-state subsidence anomalies in the Pannonian Basin, Tectonophysics, 266, 287300, 1996.

Horváth, F. and Royden, L.,: Mechanism for the formation of the intra-Carpathian basins: a review, Earth Evol., Sci., 3/4, 307316, 1981.

Horváth, F. and Rumpler, J.: The Pannonian basement: extension and subsidence of an Alpine orogene, Acta Geol. Hung., 27, 229-235, 1984.

Horváth, F., Dovenyi, P., Szalay, S., and Royden, L. H.: Subsidence, thermal and maturation history of the Great Hungarian Plain, in: Royden, L. H. and Horváth, F. (Eds.): The Pannonian Basin, AAPG Memoir, 45, Tulsa, 355-372, 1988.

Horváth, F., Szalay, A., Dövényi, P., and Rumpler, J.: Structural and thermal evolution of the Pannonian basin, in: Burns, J. (Ed.): Thermal modelling in sedimentary basins, Technip., (Paris), 339-358, 1989.

Huismans, R. S., Bertotti, G., Ciulavu, D., Sanders, C. A. E., Cloetingh, S., and Dinu, C.: Structural evolution of the Transylvanian Basin (Romania): a sedimentary basin in the bend zone of the Carpathians, Tectonophysics, 272, 249-268, 1997.

Huismans, R. S., Podladchikov, Z. Z., and Cloetingh, S. A. P. L.: The transition from passive to active rifting: The Pannonian basin, an application. Results from dynamic modelling, Terra Nova, Abstr., 9, 96, 1997.

Huraiová, M. and Konečný, P.: Teplotno-tlakové podmienky a oxidačný stav vrchného plášt'a na Južnom Slovensku (P/T conditions and oxidation state of Upper Mantle in Southern Slovakia), in: Rakús, M. and Vozár, J. (Eds.): Geodynamický model a hlbinná stavba Západných Karpát, Geologický ústav D. Štúra, Bratislava, 169-174, 1993.

Jarrard, R. D.: Relation among subduction parameters, J. Rev. Geophys., 24, 217-284, 1986.

Jiříček, R. and Seifert, P.: Paleogeography of the Neogene in the Vienna Basin and adjacent part of the Foredeep, in: Minař́ková, D. and Lobitzer, H. (Eds.): Thirty years of geological cooperation between Austria and Czechoslovakia, Prague, 89-105, 1990.

Jiříček, R.: Tektogenetický vývoj karpatského oblouku během olgocénu a neogénu, in: Mahel, M. (Ed.): Tektonické profily Západných Karpát, GÚDŠ Bratislava, 205-215, 1979.

Jischke, M. C.: On the dynamics of descending lithospheric plates and slip zones, J. Geophys. Res., 80, 4809-4813, 1975.

Kaličiak, M. and Žec, B.: Review of Neogene volcanism of Eastern Slovakia, Acta Volcanologica, 7, 87-96, 1995.

Kaličiak, M., Konečný, V., and Lexa, J.: Relationship of structure and evolution of the Neogene volcanics in Slovakia to block faulting, Geol. Práce, Správy, 88, 1989.

Karig, D. E.: Origin and development of marginal basins in the Western Pacific, J. Geophys. Res., 76, 2542-2561, 1971.

Konečný, P., Konečný, V., Lexa, J., and Huraiová, M.: Mantle xenoliths in alkali basalts of southern Slovakia, Acta Volcanologica, 7, 241-248, 1995.

Konečný, V., Lexa, J., and Hojstričová, V.: The Central Slovakia Neogene Volcanic Field: a review, Acta Volcanologica, 7, 6378, 1995a.

Konečný, V., Lexa, J., Balogh, K., and Konečný, P.: Alkali basalt volcanism in southern Slovakia: volcanic forms and time evolution, Acta Volcanologica, 7, 167-172, 1995b.

Korpás, L., Csillag-Teplánszky, E., Hámor, G., Ódor, L., Horváth, I., Fügedi, U., and Harangi, Sz.: Explanations for the geological map of Börzsöny-Visegrád Mts, Hung. Geol. Inst., 1-216, 1998.

Kováč, M., Cicha, I., Krystek, I., Slaczka, A., Stránik, Z., Oszczypko, N., and Vass, D.: Palinspastic Maps of the Western Carpathian Neogene 1:1 000 000, Geol. survey Prague, 31p, 1989.

Kováč, M., Nagymarosy, A., Soták, J., and Šútovská, K.: Late Tertiary paleogeographic evolution of the Western Carpathians, Tectonophysics, 226, 401-416, 1993.

Kováč, M. and Túnyi, I.: Interpretation of the paleomagnetic data from western part of the Cantral Western Carpathians, Mineralia slov., 27, 213-220, 1995.

Kováč, M., Kováč, P., Marko, M., Karoli, S., and Janočko, J.: The East Slovakian Basin - a complex back-arc basin, Tectonophysics, 252, 453-466, 1995.

Kováč, M., Nagymarosy, A., Oszczypko, N., Slaczka, A., Csontos, L., Marunteanu, M., Matenco, L., and Márton, E.: Palinspastic reconstruction of the Carpathian-Pannonian region during the Miocene, in: Rakús, M. (Ed.): Geodynamic evolution of the Western Carpathians, Mineralia slov. Monograph., 189-217, 1998.

Kováč, M. and Márton, E.: To rotate or not to rotate: Palinspastic reconstruction of the Carpatho-Pannonian area during the Miocene, Slov. Geol. Mag., 4, 2, 75-85, 1998.

Kováč, M.: Geodynamic, Paleogeographic and Structural Development of the Carpathian-Pannonian Region: New view on Neo- 
gene Basins of Slovakia, Veda, 1-202 (in Slovak), 2000.

Krs, M., Pruner, P., and Túnyi, I.: Paleomagnetism, paleotectonics and paleogeography of Cretaceous and Cenozoic rocks of the Western Carpathians, Geol. Carpath., 51, 3, 175-176, 2000.

Krzywiec, P., Luczkowska-Schiller, E., Sadowska, A., and Slezak, J.: Depositional model of the central part of the Carpathian foredeep basin, S Poland - Result of integrated bio- and seismostratigraphic study, Geol. Soc. Greece, Sp. Publ., 4, Proceedings of the CBGA XV Congress, 1113-1118, 1995.

Krzywiec, P. and Jochym, P.: Characteristic of the subduction zone in the Eastern Polish Carpathians - Preliminary results of flexural Modelling, Publ. Inst. Geophys. Pol. Acad. SC., M-18, 155-161, 1996.

Krzywiec, P.: Large-scale tectono-sedimentary Middle Miocene history of the central and eastern Polish Carpathian Foredeep Basin - results of seismic data interpretation, Przeglad Geol., 45, 10, 1039-1053, 1997.

Krzywiec, P. and Jochym, P.: Characteristic of the Miocene subduction zone of the Polish Carpathians: results of flexural modelling, Przeglad Geol., 45, 8, 785-792, 1997.

Lankreijer, A.: Rheology and basement control on extensional basin evolution in Central and Eastern Europe: Variscan and AlpineCarpathian-Pannonian tectonics, Vrije Universiteit, NSG Publ. No. 980 101, 158p, 1998.

Lankreijer, A. C., Bielik, M., Cloetingh, S., and Majcin, D.: Rheology predictions across the Western Carpathians, Bohemian Massif and Pannonian basin: Implication for tectonic scenarios, Tectonics, 18, 1139-1153, 1999.

Lenhey, L.: Geotermics of the Pannonian Basin and its bearing on the tectonics of basin evolution, PhD-Thesis NGS contribution No. 000 112, Amsterdam, 215p, 1999.

Lexa, J. and Konečný, V.: The Carpathian volcanic arc: A discussion, Acta Geol. Acad. Sci. Hung. 18, 279-293, 1974.

Lexa, J. and Konečný, V.: Relationship of the Carpathian volcanic arc to the geodynamic evolution of the Pannonian basin, in: Geodynamic Investigations in Czechoslovakia, Bratislava, Veda, 1979.

Lexa, J., Konečný, V., Kaličiak, M., and Hojstričová, V.: Distribúcia vulkanitov karpatsko-pannónskeho regiónu v priestore a čase (Space-time distribution of volcanics in the CarpathoPannonian region), in: Rakús, M. and Vozár, J. (Eds.): Geodynamický model a hlbinná stavba Západných Karpát, Geologický ústav D. Štúra, Bratislava, 57-70, 1993.

Lexa, J., Konečný, V., Kováč, M., and Nemčok, M.: Relationship among convergence, back-arc extension and volcanism in the Western Carpathians during Neogene, Abstracts, Europrobe workshops - Pancardi, SAV Bratislava, 65-66, 1995.

Lexa, J., Konečný, P., Hojstričová, V., Konečný, V., and Köhlerová, M.: Petrologic model of the Štiavnica stratovolcano, Central Slovakia Neogene Volcanic Field, Abstract, XVIth congress CBGA, Vienna, s. 340, 1998.

Lexa, J. and Konečný, V.: Geodynamic aspects of the Neogene to Quaternary volcanism, in: Rakús, M. (Ed.): Geodynamic development of the Western Carpathians, GS SR, Bratislava, 219-240, 1998.

Lilie, R. J. and Bielik, M.: Crustal development and tectonic models of Western Carpathians from gravity interpretations, Geol. Zborník, 43, 63-68, 1992

Lillie, R. J., Bielik, M., Babuška, V., and Plomerová, J.: Gravity modelling of the lithosphere in the Eastern Alpine-Western Carpathian-Pannonian Basin Region, Tectonophysics, 231, 215235,1994
Linzer, H. G.: Kinematic evolution of the Carpathian arc system, Terra Abstract, 7, 271, 1995.

Linzer, H. G.: Kinematics of retreating subduction along the Carpathian arc (Romania), Geology, 24, 2, 167-170, 1996.

Linzer, H. G., Frisch, W., Zweigel, P., Girbacea, R., Hann, H. P., and Moser, F: Kinematic evolution of the Romanian Carpathians, Tectonophysics, 297, 1-4, 133-156, 1998.

Márton, E., Pagáč, P., and Túnyi, I.: Paleomagnetic investigations on Late Cretaceous-Cenozoic sediments from the NW part of the Pannonian Basin, Geol. Carpath., 43, 6, 363-368, 1992.

Márton, E., Vass, D., and Túnyi, I.: Early Tertiary rotations of the Pelso megaunit and neighbouring Central West Carpathians, in: Hamršmíd, E. (Ed.): New results in Tertiary of West Carpathians II, MND Hodonín, KZPN, 16, 97-108, 1995.

Márton, E. and Márton, P.: Large scale rotation in North Hungary during the Neogene as indicated by paleomagnetic data, in: Morris, A. and Tarling, D. H. (Eds.): Paleomagnetism and tectonics of the Peri-Mediternanean region, Geol. Soc. Spec. Publ. (London), 153-173, 1996

Márton, E., Vass, D., and Túnyi, I.: Rotation of the South Slovak Paleogene and Lower Miocene rocks indicated by paleomagnetic data, Geol. Carpath., 47, 1, 31-42, 1996.

Márton, E., Vass, D., and Túnyi, I.: Counterclockwise rotations in the East Slovakia Basin, Geol. Carpath., 51, 3, 159-168, 2000.

Mason, P. R. D., Downes, H., Seghedi, I., Szakács, A., and Thirwall, M. F.: Low-pressure evolution of magmas from the Calimani, Gurghiu and Hargita Mountains, East Carpathians, Acta Volcanologica, 7, 43-52, 1995.

Mason, P. R. D., Downes, H., Thirwall, M. F., Seghedi, I., Szakács, A., Lowry, D., and Mattey, D.: Crustal Assimilation as a Major Petrogenetic Process in the East Carpathian Neogene and Quaternary Continental Margin Arc, Romania, Journal of Petrology, 37, 927-959, 1996.

Matenco, L. C.: Tectonic evolution of the outer Romanian Carpathians, The Netherlands Research School of Sedimentology (NSG) publ. 970 148, 160p, 1997.

Matenco, L., Bertotti, G., Dinu, C., and Cloetingh, S.: Tertiary tectonic evolution of the external South Carpathians and the adjacent Moesian platform (Romania), Tectonics, 16, 896-911, 1997.

Meulenkamp, J. E., Kováč, M., and Cicha, I.: On late Oligocene to Pliocene depocentre migrations and the evolution of the Carpathian-Pannonian system, Tectonophysics, 266, 301-317, 1996.

Mihaliková, A. and Šímová, M.: Geochémia a petrológia miocénno-pliocénnych alkalických bazaltov stredného a južného Slovenska (Geochemistry and petrology of Miocene-Pliocene alkali basalts in central and southern Slovakia), Záp. Karpaty, ser. Mineralogia, petrografia, geochémia, metalogenéza, 12, 7-142, 1989.

Morley, C. K.: Models for relative motion of crustal blocks within the Carpathian region, based on restorations of the outer Carpathian thrust sheets, Tectonics, 15, 4, 885-904, 1996.

Nagymarosy, A.: Paleogeographical and paleontological outlines of some Intracarpathian Paleogene basins, Geol. Zbor. Geol. Carpath., 41, 259-274, 1990.

Nemčok, M. and Lexa, J.: Evolution of the Basin and range structure around the Žiar mountain range, Geologica Carpatica, Bratislava, 41, 3, 229-258, 1990.

Nemčok, M., Hók, J., Kováč, P., Marko, F., Madarás, J., and Bezák, V.: Tektonika Západných Karpát v terciéri (Tectonics of Western Carpathians during Tertiary), in: Rakús, M. and Vozár, J. (Eds.): 
Geodynamický model a hlbinná stavba Západných Karpát, Geologický ústav D. Štúra, Bratislava, 263-268, 1993.

Nemčok, M., Pospíšil, L., Lexa, J., and Donelick, R. A.: Tertiary subduction and slab break-off model of the CarpathianPannonian region, Tectonophysics 295, 307-340, 1998.

Ninkovich, D. and Hayes, J. D.: Mediterranean island arcs and origin of high potash volcanoes, Earth. Planet. Sci. Letters, 16, 331345, 1972.

Nurr, A., Dvorkin, J., Mavko, G., and Ben-Avraham, Z.: Speculations on the origins and fate of bacarc basins, Annali di Geofisica, Spec. issue, 36, 155-163, 1993.

Oszczypko, N.: Evolution of the Magura basin during the Upper Cretaceous and Paleogene, Przegl. Geol., 40, 7, 397-404, 1992.

Oszczypko, N.: The Miocene dynamics of the Carpathian Foredeep in Poland, Przegl. Geol., 44, 10, 1007-1018, 1996.

Oszczypko, N.: The Early Miocene Carpathian peripheral foreland basin (Western Carpathians, Poland), Przegl. Geol., 45, 10, 1054-1066, 1997.

Oszczypko, N. and Slaczka, A.: An attempt to palinspastic reconstruction of Neogene basins in the Carpathian foredeep, Ann. Soc. Geol. Pol., 55, 5-75, 1986.

Oszczypko, N. and Slaczka, A.: The evolution of the Miocene basins in the Polish Flysch Carpathians and their foreland, Geol. Zbor., Geol. Carpath., 40, 1, 23-36, 1989.

Oszczypko, N. and Tomas, A.: Tectonic evolution of the marginal part of the Polish Flysch Carpathians in the Middle Miocene, Kvart. Geol., 29, 109-128, 1985.

Panaiotu, C.: Paleomagnetic constraints on the geodynamic history of Romania, Reports on Geodesy 7(37), Monograph of Southern Carpathians, Warshaw Institute of Technology, 49-71, 1998.

Patrascu, St., Bleahu, M., Panaiotu, C., and Panaiotu, C. E.: The paleomagnetism of the Upper Cretaceous magmatic rocks in the Banat area of the South Carpathians: tectonic implications, Tectonophysics, 213, 341-352, 1992.

Patrascu, St., Bleahu, M., and Panaiotu, C.: Tectonic implications of paleomagnetic research into Upper Cretaceous magmatic rocks in the Apuseni Mountains, Romania, Tectonophysics, 180, 309322, 1990.

Patrascu, St., Panaiotu, C., Seclaman, M., and Panaiotu, C. E.: Timing of rotational motion of Apuseni Mountains (Romania): paleomagnetic data from Tertiary magmatic rocks, Tectonophysic, 233, 163-176, 1994.

Pécskay, Z., Edelstein, O., Seghedi, I., Szakács, A., Kováč, M., Crihan, M., and Bernad, A.: K-Ar datings of Neogene-Quaternary calc-alkaline volcanic rocks in Romania, Acta Volcanologica, 7, 53-61, 1995.

Pécskay, Z., Lexa, J., Szakács, A., Kadosc-Balogh, I., Seghedi, I., Konečný, V., Kováč, M., Márton, E., Kalinčiak, M., Széky-Fux, V., Póka, T., Gyarmati, P., Edelstein, O., Roşu, E., and Žec, B.: Space and time distribution of Neogene and Quarternary volcanism in the Carpatho-Pannonian Region, Acta Volcanologica, 7, 15-28, 1995.

Peresson, H. and Decker, K.: The Tertiary dynamics of the northern Eastern Alps (Austria): changing paleostresses in a collisional plate boundary, Tectonophysics, 272, 125-157, 1997.

Plašienka, D. and Kováč, M.: How to loop Carpathians - an attempt to reconstruct Meso-Cenozoic palinspastic history of the carpathian orocline, Geol. Carpathica, 50, spec. issue, 163-165, 1999.

Póka, T.: Neogene and Quaternary volcanism of the CarpathianPannonian region: changes in chemical composition and its relationship to basin formation, in: Royden, L., Horváth, F. (Eds.):
The Pannonian Basin. A study in basin evolution, AAPG Memoir, 45, 257-276, 1988.

Praus, O., Pečová, J., Petr, V., Babuška, L., and Plomerová, Magnetotelluric and seismological determination of lithosphereasthenosphere transition in central Europe, Phys. Earth. Planet. Inter., 60, 212-228, J. 1990.

Ratschbacher, L., Merle, O., Davy, P. and Cobbols, P.: Lateral extrusion in the Eastern Alps: Part 1, Boundary conditions and experiments scaled for gravity, Tectonics, 10, 245-256, 1991a.

Ratschbacher, L., Frisch, W., Linzer, H. G., and Merle, O.: Lateral extrusion in the Eastern Alps, Part 2, Structural analysis, Tectonics, 10, 257-271, 1991b.

Ratschbacher, L., Frisch, W., Linzer, H. G., Sperner, B., Meschede, M., Decker, K., Nemčok, M., Nemčok, J., and Grygar, R.: The Pieniny Klippen Belt in the Western Carpathians of northern Slovakia: structural evidence for transpression, Tectonophysics, 225, 471-484, 1993.

Roure, F., Roca, E., and Sassi, W.: The Neogene evolution of the Outer Carpathians flysch units (Poland, Ukraine and Romania): Kinematics of a foreland fold and thrust belt system, Sediment. Geol., 86, 177-201, 1993.

Roşu, E., Pécskay, Z., Stefan, A., Popescu, G., Panaiotu, C., and Panaiotu, C. E.: The evolution of the Neogene volcanism in the Apuseni Mountains (Romania): constraints from new K-Ar data, Geologica Carpathica, 48, 353-359, 1997.

Roşu, E., Szakács, A., Downes, H., Seghedi, I., Pécskay, Z., and Panaiotu, C.: The origin of Neogene Calc-alkaline and alkaline magmas in the Apuseni Mountains, Romania: the adakite connection, Romanian J. of Mineral Dep., 79, suppl. 2, 3-23, 2001.

Royden, L. H. and Keen, C. E.: Rifting process and thermal evolution of the continental margin of eastern Canada determined from subsidence curves, Earth and Planetary Science Letters, 51, 343-361, 1980.

Royden, L. H., Horváth, F., and Burchfield, B. C.: Transform faulting, extension, and subduction in the Carpathian Pannonian region, Geol. Soc. Am. Bull., 93, 717-25, 1982.

Royden, L. H., Horváth, F., and Rumpler, J.: Evolution of the Pannonian basin system, 1. Tectonics, Tectonics, 2, 61-90, 1983a.

Royden, L. H., Horváth, F., Nagymarosy, A., and Stegena, L.: Evolution of the Pannonian basin system 2. Subsidence and thermal history, Tectonics, 2, 91-137, 1983b.

Royden, L. H. and Karner, G.: Flexure of lithosphere beneath Apennine and Carpathian foredeep basins: evidence for an insufficient topographic load, Am. Assoc. Petr. Geol. Bull., 68, 704-712, 1984.

Royden, L. H.: The Vienna basin: a thin skinned pull apart basin, in: Biddle, K. T. and Christie-Blick, N. (Eds.): Strike-slip deformation, basin formation and sedimentation, The Society of Economic Paleontologists and Mineralogists, Spec. publ. 37, Tulsa, 319-339, 1985.

Royden, L. H. and Dövényi, P.: Variations in extensional styles at depth across the Pannonian basin system, in: Royden, L. and Horváth, F. (Eds.): The Pannonian Basin. A study in basin evolution, AAPG Memoir, 45, 235-253, 1988.

Royden, L. H.: Late Cenozoic tectonics of the Pannonian basin system, in: Royden, L. and Horváth, F. (Eds.): The Pannonian Basin. A study in basin evolution, AAPG Memoir, 45, 27-48, 1988.

Royden, L. and Burchfield, B. C.: Arc systematic variations in thrust belt style related to plate boundary processes (the Western Alps versus the Carpathians), Tectonics, 8, 51-61, 1989.

Royden, L. H.: The tectonic expression of slab pull at continental 
convergent boundaries, Tectonics, 12, 2, 303-325, 1993a.

Royden, L. H.: Evolution of retreating subduction boundaries formed during continental collision, Tectonics, 12, 629-638, $1993 b$.

Salters, J. M., Hart, S. R., and Pantó, G.: Origin of late Cenozoic volcanic rocks of the Carpathian arc, Hungary, in: Royden, L. and Horváth, F. (Eds.): The Pannonian Basin. A study in basin evolution, AAPG Memoir, 45, 279-292, 1988.

Sanders, C. A. E., Andriessen, P. A. M., and Cloetingh, S. A.P. L.: Life cycle of the East Carpathian orogen: Erosion history of a doubly vergent critical wedge assessed by fission track thermochronology. J. of Geophys. Res. - Solid Earth, 104, 29095 $29112,1999$.

Sandulescu, M.: Geotectonica Romaniei (in Romanian), Ed. Tehnica, Bucuresti, 450p, 1984.

Sandulescu, M.: Cenozoic tectonic history of the Carpathians, in: Royden, L. and Horváth, F. (Eds.): The Pannonian Basin. A study in basin evolution, AAPG Memoir, 45, 17-26, 1988.

Sandulescu, M., Krautner, H. G., Balintoni, I., Russo-Sandulescu, D., and Micu, M.: The structure of the East Carpathians (Moldavia-Maramures area), Carp.-Balc. Assoc., XII Congr., Guide to Excursion B1, 1981.

Šefara, J., Bielik, M., Konečný, P., Bezák, V., and Hurai, V.: The late stage of development of Western Carpathian lithosphere and its interaction with astenosphere, Geol. Carpath., 47, 6, 339-347, 1996.

Seghedi, I., Szakács, A., and Mason, P.R. D.: Petrogenesis and magmatic evolution in the East Carpathian Neogene volcanic arc (Romania), Acta Volcanologica, 7, 135-144, 1995.

Soták, J., Birǒn, A., and Spišiak, J.: The Penninic "pull appart" dome in the pre-Neogene basement of the Transcarpathian depression (Eastern Slovakia), Geol. Carpathica, 44, 11-16, 1993.

Spakman, W.: Tomographic images of the upper mantle below central Europe and the Mediterranean, Terra Nova, 2, 542-553, 1990.

Spakman, W., Van der Lee, S., and Van der Hilst, R.: Traveltime tomography of the European-Mediterranean mantle down to 1400 km, Physics. Earth Planet. Inter. (Amsterdam), 79, 3-74, 1993.

Sperner, B. and the SFB-461 working group: The Vrancea slab (SECarpathians, Romania): Seismicity, stress field, and detachment models, in: Ádám, A., Szarka, L., and Szendroi, G. (Eds.): Abstracts, Pancardi 2001. Geodetic and Geophysical Research Institute of the HAS, Sopron, CP-26, 2001.

Stegena, L., Geczy, B., and Horváth, F.: Late Cenozoic evolution of the Pannonian Basin, Tectonophysics, 26, 71-90, 1975.

Szabó, C., Harangi, Sz., and Csontos, L.: Review of Neogene and Quaternary volcanism of the Carpathian- Pannonian region,
Tectonophysics, 208, 243-256, 1992.

Szakács, A. and Seghedi, I.: The Calimani-Gurghiu-Hargita volcanic chain, East Carpathians, Romania: volcanological features, Acta Volcanologica, 7, 145-153, 1995.

Tari, G. and Horváth, F.: Middle Miocene extensional collapse in the Alpine-Pannonian transitional zone, in: Horváth, F., Tari, G., and Bokor, K. (Eds.): Extensional collapse of the Alpine orogene and hydrocarbon prospects in the basement and fill of the western Pannonian Basin, AAPG Inter. Conf. and Exhib., Nice, France, Guidebook to fieldtrip No. 6, 75-105, 1995.

Tari, G., Horváth, F., and Rumpler, J.: Styles of extension in the Pannonian Basin, Tectonophysics, 208, 203-219, 1992.

Tollmann, A.: Die alpidischen Gebirgsbildungs-Phasen in den Ostalpen und Westkarpaten, Geotektonische Forschungen (Stuttgart), 21, 156p, 1966

Tomek, Č. and Hall, J.: Subducted continental margin imaged in Carpathians of Czechoslovakia, Geology, 21, 535-538, 1993.

Tomek, Č.: Deep crustal structure beneath the central and inner West Carpathians, Tectonophysics, 226, 417-431, 1993.

Tomek, Č., Ibrmayer, I., Koráb, T., Biely, A., Dvořáková, L., Lexa, J., and Zbořil, L.: Crustal structure of Western Carpathians on the deep reflection seismic section 2T, Miner. Slovaca, 21, 3-26, 1989.

Túnyi, I. and Kováč, M.: Paleomagnetic investigation of the Neogene sediments from the Little Carpathians, Contrib. Geophys. Instr. Slov. Acad. Sci., 21, 125-146, 1991.

Túnyi, I. and Márton, E.: Indications for large Tertiary rotation in the Carpathian - Northern Pannonian region outside the North Hungarian Paleogene Basin, Geol. Carpath., 47, 1, 43-50, 1996.

Uyeda, S.: Some basic problems in the trench-arc-back-arc system, in: Talwani, M. and Pitman, W. C. (Eds.): Island Arcs, Maurice Ewing Series, A. G. U, 1, 1-14, 1977.

Von Blanckenburg, F. and Davies, J. H.: Slab breakoff: a model for syncollisional magmatism and tectonics in the Alps, Tectonics, 14, 120-131, 1995.

Wielleman, R. and Davies, G. F.: Bending stress in subducted lithosphere, Geophys. J. R. Astron. Soc., 71, 215-224, 1982.

Wilson, M.: Igneous petrogenesis, Harper Colins Academic, London, 466p, 1989.

Wortel, M. J. R. and Spakman, W.: Structure and dynamics of subducted lithosphere in the Medeterranean region, Proc. Kon. Ned. Acad. v Wetensch., 95, 325-347, 1992.

Yokokura, T.: On subduction dip angles, Tectonophysics, 77, 6377, 1981

Zoetemeijer, R., Tomek, Č., and Cloetingh, S.: Flexural expression of European continental lithosphere under the western outer Carpathians, Tectonics, 18, 843-861, 1999. 